\title{
Water-driven microbial nitrogen transformations in biological soil crusts causing atmospheric nitrous acid and nitric oxide emissions
}

\author{
S. Maier (iD ${ }^{1,2,7 凶}$, A. M. Kratz (iD ${ }^{2,7}$, J. Weber ${ }^{2}$, M. Prass (iD ${ }^{2}$, F. Liu (iD ${ }^{2,3}$, A. T. Clark ${ }^{1}$, R. M. M. Abed ${ }^{4}$, H. Su ${ }^{2}$, Y. Cheng (D) ${ }^{2}$, T. Eickhorst ${ }^{5}$, \\ S. Fiedler ${ }^{6}$, U. Pöschl ${ }^{2}$ and B. Weber (iD ${ }^{1,2}$ 药
}

(C) The Author(s) 2021

\begin{abstract}
Biological soil crusts (biocrusts) release the reactive nitrogen gases $\left(\mathrm{N}_{\mathrm{r}}\right)$ nitrous acid $(\mathrm{HONO})$ and nitric oxide (NO) into the atmosphere, but the underlying microbial process controls have not yet been resolved. In this study, we analyzed the activity of microbial consortia relevant in $\mathrm{N}_{\mathrm{r}}$ emissions during desiccation using transcriptome and proteome profiling and fluorescence in situ hybridization. We observed that $<30 \mathrm{~min}$ after wetting, genes encoding for all relevant nitrogen ( $\mathrm{N}$ ) cycling processes were expressed. The most abundant transcriptionally active $\mathrm{N}$-transforming microorganisms in the investigated biocrusts were affiliated with Rhodobacteraceae, Enterobacteriaceae, and Pseudomonadaceae within the Alpha- and Gammaproteobacteria. Upon desiccation, the nitrite $\left(\mathrm{NO}_{2}{ }^{-}\right)$content of the biocrusts increased significantly, which was not the case when microbial activity was inhibited. Our results confirm that $\mathrm{NO}_{2}{ }^{-}$is the key precursor for biocrust emissions of $\mathrm{HONO}$ and $\mathrm{NO}$. This $\mathrm{NO}_{2}{ }^{-}$accumulation likely involves two processes related to the transition from oxygen-limited to oxic conditions in the course of desiccation: (i) a differential regulation of the expression of denitrification genes; and (ii) a physiological response of ammonia-oxidizing organisms to changing oxygen conditions. Thus, our findings suggest that the activity of $\mathrm{N}$-cycling microorganisms determines the process rates and overall quantity of $\mathrm{N}_{\mathrm{r}}$ emissions.
\end{abstract}

The ISME Journal (2022) 16:1012-1024; https://doi.org/10.1038/s41396-021-01127-1

\section{INTRODUCTION}

Soils host one of the most diverse microbiomes on Earth [1] with abundances of prokaryotes (bacteria and archaea) reaching $4-20 \times 10^{9} \mathrm{~cm}^{-3}$ [2]. These microorganisms are one of the major biotic drivers of the biogeochemical cycles of carbon $(C)$, nitrogen $(\mathrm{N})$, oxygen $\left(\mathrm{O}_{2}\right)$, and sulphur [3]. Biological soil crusts (biocrusts) represent a special type of soil microbiome, colonizing the uppermost layer of the soil in arid and semi-arid ecosystems worldwide [4]. They are composed of a photoautotrophic upper layer with poikilohydric (desiccation-tolerant) organisms, such as cyanobacteria, algae, lichens, and bryophytes, and a layer below with heterotrophic microorganisms [5-8]. Biocrusts occur globally in regions with dry microclimatic conditions, such as drylands. They cover approximately $12 \%$ of the Earth's terrestrial surface, corresponding to an area of $\sim 18 \times$ $10^{6} \mathrm{~km}^{2}[9,10]$. In some desert regions, up to $70 \%$ of the soil surface is covered by biocrusts [4].

Nitrogen represents an essential element for all living organisms and most of them depend on bioavailable forms, like ammonium $\left(\mathrm{NH}_{4}{ }^{+}\right)$and nitrate $\left(\mathrm{NO}_{3}{ }^{-}\right)$, for growth. The availability of these reactive forms of $\mathrm{N}$ relies on metabolically versatile microorganisms carrying out $\mathrm{N}$-transforming reactions, which are spatially and/or temporally separated [11]. Microbial transformations of $\mathrm{N}$ comprise the distinct processes of $\mathrm{N}$ fixation, assimilation into organic $\mathrm{N}$, ammonification (degradation of organic $\mathrm{N}$ ), nitrification, denitrification, and anaerobic ammonium oxidation (anammox) [11]. The $\mathrm{N}$-transforming processes have considerably different fluxes, as the largest $\mathrm{N}$ fluxes are attributed to the interconversion of ammonia $\left(\mathrm{NH}_{3}\right)$ and organic $\mathrm{N}$ (ammonification and ammonium assimilation) [11].

Nitrogen oxides $\left(\mathrm{NO}_{\mathrm{x}}=\mathrm{NO}+\mathrm{NO}_{2}\right)$ play a vital role in the formation of ozone $\left(\mathrm{O}_{3}\right)$ in the troposphere [12]. Tropospheric $\mathrm{O}_{3}$ is a component of photochemical smog and a short-lived climate pollutant $[13,14]$. Sources of tropospheric $\mathrm{O}_{3}$ are the stratosphere and in situ photochemical $\mathrm{O}_{3}$ formation that is dependent on the concentration of $\mathrm{NO}_{x}$ [12]. Major sources of $\mathrm{NO}_{x}$ in the troposphere are the combustion of fossil fuels, biomass burning, soil microbial activity, and lightning [15]. Nitrous acid (HONO) is one of the precursors of the hydroxyl radical $(\mathrm{OH} \bullet)$. Through formation of $\mathrm{OH} \bullet$, HONO regulates the oxidation capacity of the atmosphere, which leads to the removal of most trace gases emitted by natural and anthropogenic activities [16]. Proposed atmospheric reactions for the formation of HONO involve gas phase and heterogeneous reactions of $\mathrm{NO}_{x}[17-21]$.

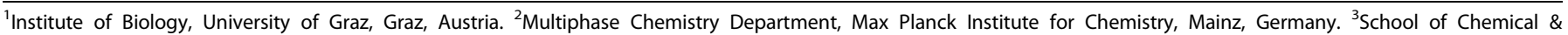

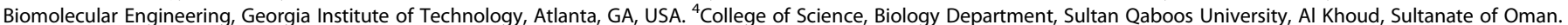

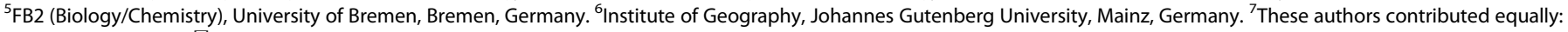
S. Maier, A. M. Kratz. ${ }^{凶}$ email: stefanie.maier@uni-graz.at; bettina.weber@uni-graz.at 
Gas exchange studies showed that the atmospherically relevant trace gases HONO and NO can be emitted from soil and biocrusts [22-30]. About $15 \%$ of the $\mathrm{NO}_{\mathrm{x}}$ emissions to the atmosphere originate from soils under natural vegetation [31], with substantial amounts being emitted as NO due to the microbial processes nitrification and denitrification [32-35]. Evidence suggests that also biogenic sources of $\mathrm{HONO}$ exist in soil $[23,25]$. It was suggested that soil nitrite $\left(\mathrm{NO}_{2}{ }^{-}\right)$, derived from the biological processes nitrification and denitrification, can be an important source of atmospheric HONO [22] and that acidic conditions (at least at the soil surface) are needed [26, 30, 36, 37]. More recently, pure culture studies reported that ammonia-oxidizing bacteria (AOB) and archaea (AOA) are involved in the formation of HONO $[23,38]$, and thus also $\mathrm{NH}_{3}$ concentrations are likely relevant. Hydroxylamine $\left(\mathrm{NH}_{2} \mathrm{OH}\right)$ has been identified as a further precursor for the formation of HONO [38]. Peak fluxes of HONO were also related to the abundance of nitrifying microbes in agricultural and urban soil and stable isotope tracer experiments demonstrated the microbial oxidation of $\mathrm{NH}_{4}{ }^{+}$to $\mathrm{HONO}$ [39]. Microbial $\mathrm{NO}_{3}{ }^{-}$ reduction (denitrification) was described as another pathway for HONO production via soil $\mathrm{NO}_{2}{ }^{-}$in aerobic, agricultural soils [40]. For $\mathrm{O}_{2}$-limited microsites in wet soils, $\mathrm{HONO}$ emissions were attributed to $\mathrm{NO}_{2}{ }^{-}$, formed by microbial $\mathrm{NO}_{3}{ }^{-}$reduction [41].

In multiple studies, $\mathrm{NO}$ and HONO emissions were strongly related to the water content and emissions from drying soil, soil bacteria, and biocrusts were minimum at high moisture, i.e., 100\% water holding capacity (WHC) $[22,23,25,26]$. With progressive moisture reduction, $\mathrm{HONO}$ and $\mathrm{NO}$ emissions started to rise, reaching maximum values around $20-30 \%$ WHC. This study aims to elucidate the microbial processes involved in $\mathrm{HONO}$ and NO production. We combined continuous, dynamic NO and HONO flux measurements with fluorescence in situ hybridization (FISH), and transcriptome (microarray) and proteome profiling of drying biocrusts. For this, biocrust samples were wetted to full WHC and continuous flux measurements were conducted over the desiccation cycle. At characteristic stages, i.e., at full WHC, before the emission maximum, and shortly before complete drying, the flux measurements were stopped to analyze the activity and abundance of microorganisms. The functional gene microarray (FGA) was applied to identify pathways and the taxonomic identity of microorganisms involved in $\mathrm{N}$ transformations. Fluorescence in situ hybridization was used to study the spatial distribution and abundance of microbes that contribute to the $\mathrm{N}$ cycle in biocrusts. In addition, the $\mathrm{NO}_{2}{ }^{-}$and $\mathrm{NO}_{3}{ }^{-}$content of the samples was analyzed before and after a desiccation cycle, and in a parallel approach the relevance of biotic processes was analyzed by suppressing the biotic activity by methyl iodide $\left(\mathrm{CH}_{3} \mathrm{l}\right)$ treatment of the samples. With this combined approach, we aimed to (i) analyze the response of microorganisms to wetting following a severe dry period, (ii) identify the organisms responsible for the different $\mathrm{N}$-transforming processes, and (iii) investigate the temporal connection between microbial metabolic activity and the emissions of HONO and NO. The results of this study should help to elucidate the underlying microbial processes causing the release of $\mathrm{NO}$ and HONO emissions by biocrusts.

\section{MATERIAL AND METHODS}

\section{Study area and sampling}

Samples were collected within the Succulent Karoo biome (Fig. S1), stretching along the Atlantic coast of southwestern Namibia and South Africa into the dry intermountain valleys and basins within the Cape Fynbos biome [42]. The area is characterized by a semi-arid climate with an annual precipitation of $\sim 131 \mathrm{~mm}$ occurring during the winter months (July and August) and a mean air temperature of $19.4^{\circ} \mathrm{C}[43,44]$. More information on the study area is available in Haarmeyer et al. [43] and additional information on the sampling procedure is available in the Supplementary Material 1. a Dynamic chamber measurement

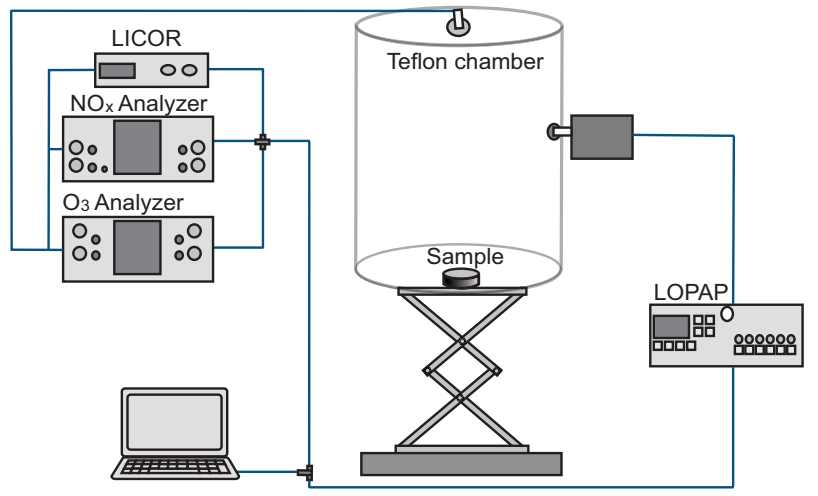

b Emission patterns

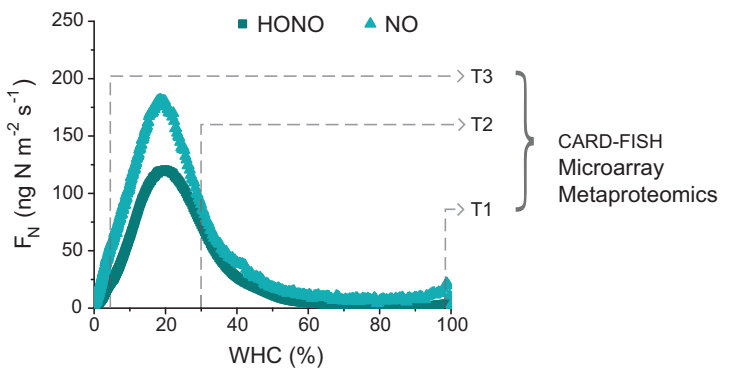

Fig. 1 Overview of the experimental setup. a Dynamic chamber system for measurements of reactive nitrogen $\left(\mathrm{N}_{\mathrm{r}}\right)$ fluxes; (b) Representative emission curves/patterns with three stages during a desiccation cycle (T1: early wetting; $99 \%$ mean water holding capacity (WHC); T2: intermediate drying; $30 \%$ mean WHC; T3: late drying; $\sim 4 \%$ mean WHC). At each of the stages, the dynamic chamber measurements were stopped and microarray, metaproteomic, and CARD FISH analyses were conducted (the latter only at T1 and T2).

\section{Overall experimental setup}

Dynamic chamber measurements were conducted at $25^{\circ} \mathrm{C}$ in the dark (Fig. 1a). Biocrust samples were wetted with sterile, artificial rain water [45] up to full WHC. At three characteristic stages during one desiccation cycle (wetting and subsequent drying), the experiment was stopped, samples $(n=$ 3) were removed from the chamber, and used for further analyses (Fig. 1b). The first stage was 20-30 min after wetting (T1; mean 99\% WHC; Table S1a), the second at increasing emissions prior to maximum $\mathrm{N}_{\mathrm{r}}$ fluxes (T2; mean 30\% WHC; 3.4-5 h after wetting; Table S1a), and the third shortly before complete desiccation (T3; mean 4\% WHC; 6.3-8 h after wetting; Table S1a). One part of the replicate of each desiccation stage was used for RNA extraction and subsequent microarray analysis (GeoChip) to detect the actively transcribed genes involved in biogeochemical cycling of $\mathrm{N}$ and a second part was used for mass spectrometry-based metaproteomics. A third part was used to quantify the number of bacteria, archaea and nitriteoxidizing bacteria (NOB) by means of CARD-FISH (Catalyzed Reporter Deposition Fluorescence in situ Hybridization), but here only samples at T1 and $\mathrm{T} 2$ were investigated (Fig. 1b). In addition, we analyzed the $\mathrm{NO}_{2}{ }^{-}$and $\mathrm{NO}_{3}{ }^{-}$contents before (Pre) and after a desiccation cycle (Post) and the relevance of biotic processes was tested by suppressing the biotic activity by means of a $\mathrm{CH}_{3} \mathrm{l}$ treatment. Furthermore, the $\mathrm{O}_{2}$ concentration was measured using microsensors at T1 and T2. For details on soil analyses and local measurements of $\mathrm{O}_{2}$, see Supplementary Material 1.

\section{Dynamic chamber measurements}

The measurement of $\mathrm{HONO}$ and $\mathrm{NO}$ emissions was conducted using a dynamic Teflon chamber (Fig. 1a; Supplementary Material 1). The emissions and mixing ratios of $\mathrm{NO}, \mathrm{HONO}, \mathrm{NO}_{2}$ (nitrogen dioxide) and $\mathrm{H}_{2} \mathrm{O}$ were measured at the outlet of the chamber (volume of $0.047 \mathrm{~m}^{3}$ ). NO and $\mathrm{NO}_{2}$ were analyzed with a gas chemiluminescence detector equipped with a blue light converter (Model 42 C, Thermo Electron Corporation, 
a

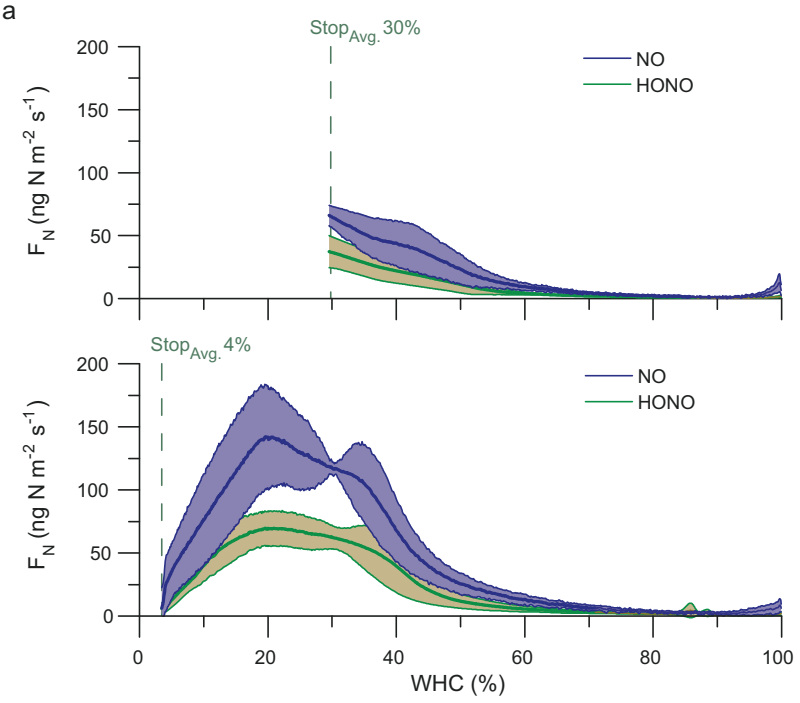

b

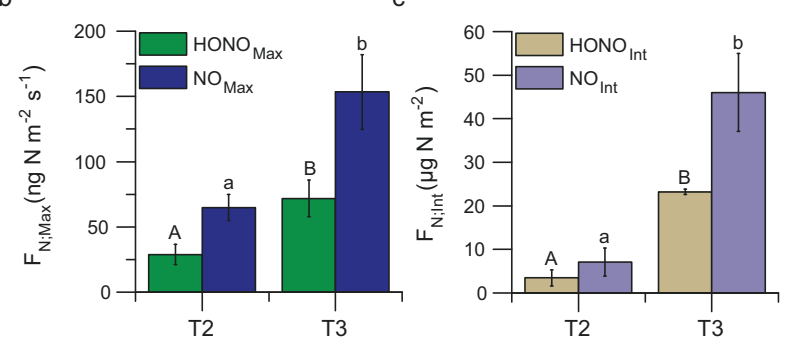

Fig. 2 Reactive nitrogen emissions along a desiccation cycle. a Average $\mathrm{HONO}$ and $\mathrm{NO}$ emission curves along a desiccation cycle of cyanobacteria-dominated biocrusts from South Africa $\left(25^{\circ} \mathrm{C}\right.$ and in the dark) stopped at different stages during desiccation (T2, T3). Lines indicate the mean fluxes and shaded areas the standard deviation; (b) Comparison of maximum HONO and NO as well as (c) integrated $\mathrm{HONO}$ and $\mathrm{NO}$ emissions of the measurements stopped at different stages during desiccation $(\mathrm{T} 2, \mathrm{~T} 3)$. At $\mathrm{T} 2$ the samples had a mean WHC of $\sim 30 \%$ and at T3 $\sim 4 \% ; n=3$.

Waltham, Massachusetts, USA). HONO was detected spectrophotometrically using a long path absorption photometer (LOPAP, QUMA Elektronik \& Analytik $\mathrm{GmbH}$, Wuppertal, Germany). Full details of the chamber measurements are given in the Supplementary Material 1.

\section{Quantification of bacterial, archaeal and NOB populations in soil samples by CARD-FISH \\ CARD-FISH allows the quantification of soil microorganisms and the analysis of spatial and temporal dynamics of native microbial populations [46]. We utilized this method to obtain information on the cell number of archaeal and bacterial cells and NOB at $\mathrm{T} 1$ and $\mathrm{T} 2$ in different biocrust layers during the desiccation cycle. \\ Samples of the upper photoautotrophic (0- $\sim 0.5 \mathrm{~mm}$ depth) and the lower heterotrophic layer ( $0.5-9 \mathrm{~mm}$ depth) were analyzed at T1 and T2 to study the temporal and spatial distribution of the microbial populations. For details on the CARD-FISH procedure, see the Supplementary Material 1.}

\section{GeoChip functional gene microarray}

We applied the FGA GeoChip 5.0, manufactured by Agilent Technologies (Santa Clara, CA, USA), to analyze the microbial transcriptional activity of genes involved in $\mathrm{N}$-cycling processes within biocrusts and its change over the course of a desiccation cycle [47, 48]. As the probes on GeoChip are based on gene sequences from pure cultures or from environmental sequences of known taxonomic groups, the hybridization data enables an assignment of the metabolic capabilities to bacterial and archaeal groups. For information on RNA extraction, CDNA synthesis and data processing see Supplementary Material 1.

\section{Mass spectrometry-based metaproteomics}

Mass spectrometry-based metaproteomics was used to determine which proteins were produced during the three characteristic stages of desiccation. The study of the entire set of proteins, resulting from cellular processes of microorganisms within their natural environment, provides insights into the microbial activity patterns [49]. Detailed information on the analytical procedure is available in the Supplementary Material 1.

\section{RESULTS}

$\mathbf{N}_{\mathbf{r}}$ emissions and mineral nitrogen content of biocrusts Over the course of the flux measurements, the highest HONO and $\mathrm{NO}$ emissions were observed at $\sim 20 \%$ WHC (mean max. HONO: $71.82 \pm 14.0 \mathrm{ng} \mathrm{N} \mathrm{m}^{-2} \mathrm{~s}^{-1}$; mean max. NO: $153.49 \pm 28.63 \mathrm{ng} \mathrm{N}$ $\mathrm{m}^{-2} \mathrm{~s}^{-1}$ ). The maximum $\mathrm{HONO}$ and $\mathrm{NO}$ values at T2 were significantly lower as compared to T3 (Fig. 2; $\mathrm{HONO}_{\text {Max }}$ : DF $=4, t$ value $=-4.64, p=0.01 ; \mathrm{NO}_{\mathrm{Max}}$ : $\mathrm{DF}=4, t$ value $=-2.82, p=0.048$; Table S1b), since the measurements were stopped before the maximum emissions were reached. Also the integral emissions of HONO and NO were higher for the samples stopped at T3 as compared to those stopped at $\mathrm{T} 2\left(\mathrm{HONO}_{\text {Int }}\right.$ : $\mathrm{DF}=4, t$ value $=$ $-17.69, p=6.00 \times 10^{-5} ; \mathrm{NO}_{\text {Int }}: \mathrm{DF}=4, t$ value $=-7.08, p=0.002$; Fig. 2; Table S1b).

Prior to full desiccation cycles, the $\mathrm{NO}_{2}{ }^{-}-\mathrm{N}$ and $\mathrm{NO}_{3}{ }^{-}-\mathrm{N}$ contents of biocrusts were similar in control and $\mathrm{CH}_{3} \mathrm{l}$ treated samples (Fig. 3a). After a desiccation cycle, the $\mathrm{NO}_{2}{ }^{-}-\mathrm{N}$ and $\mathrm{NO}_{3}{ }^{-}-$ $\mathrm{N}$ contents of the control samples tended to be higher, with a statistically significant increase registered for the $\mathrm{NO}_{2}{ }^{-}-\mathrm{N}$ content ( $q=6.607, p=0.007, n=3$; Fig. 3a; Table S1c). Samples treated with $\mathrm{CH}_{3}$ l showed low $\mathrm{NO}_{2}{ }^{-} \mathrm{N}$ and $\mathrm{NO}_{3}{ }^{-}-\mathrm{N}$ contents in a similar range as the samples analysed before the desiccation experiment (Fig. 3a).

\section{Local measurements of $\mathrm{O}_{2}$}

The average $\mathrm{O}_{2}$ saturation varied depending on the water content of the biocrust. At $\mathrm{T} 1 \quad(\sim 99 \% \mathrm{WHC}), \mathrm{O}_{2}$ was limited in the photoautotrophic and more strongly in the heterotrophic layer. At T2 ( 30\% WHC) we detected high $\mathrm{O}_{2}$ concentrations throughout the biocrust (Fig. 3b).

\section{Spatial and temporal distribution and abundance of microbial populations}

Cell numbers of bacteria and archaea were highest in the upper layer at T2 showing values of $1.0 \times 10^{9}$ and $2.3 \times 10^{8}$ cells per gram of soil, respectively (Fig. 3c). The number of bacterial cells per gram of soil was 4.5-7.5 times higher than that of archaea and about $1 \%$ of the bacteria belonged to the group of NOB (Fig. 3c). Bacterial cell numbers and NOB cell numbers were significantly higher in the upper layer compared to the one below (Bayesian hierarchical model, $p<0.05, n=3$ ). In addition, the upper biocrust layer showed significantly higher archaeal counts compared to the lower layer for T1 and T2 (Bayesian hierarchical model, $p<0.05, n$ $=3$ ). For bacterial cell numbers and NOB, no statistically significant differences were observed between $\mathrm{T} 1$ and $\mathrm{T} 2$. On the contrary, the number of archaea in the upper biocrust layer increased significantly by $72 \%$ from T1 to T2 (Bayesian hierarchical model, $p<0.05, n=3$ ). In relation to all prokaryotic cells, the percentage of archaea increased from $11.7 \%$ at $\mathrm{T} 1$ to $18.2 \%$ at $\mathrm{T} 2$, whereas in the lower biocrust layer no clear change was detectable. We were unable to detect signals when using the probe Nso1225 for AOB (Table S2).

\section{Microbes involved in nitrogen-transforming processes}

Hybridization of cDNA was achieved for an average of $27.6 \%$ of the 57,000 probes (Table S3), showing that the procedure worked properly [48]. $13 \%$ of the probes with positive hybridization signals could be allocated to the category of $\mathrm{N}$-transforming processes (Table S3). More explicitly, mRNA transcripts of genes 


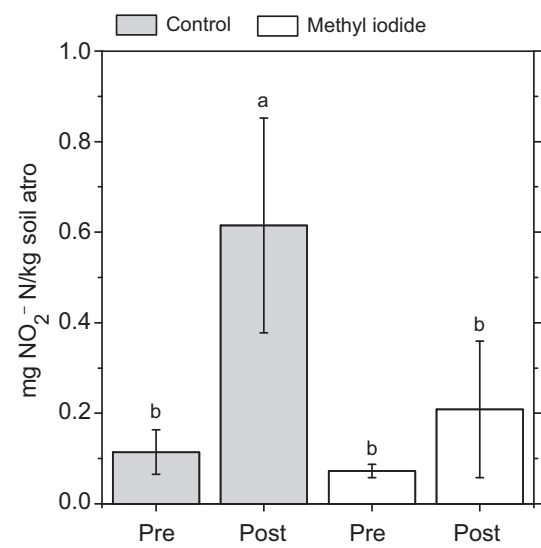

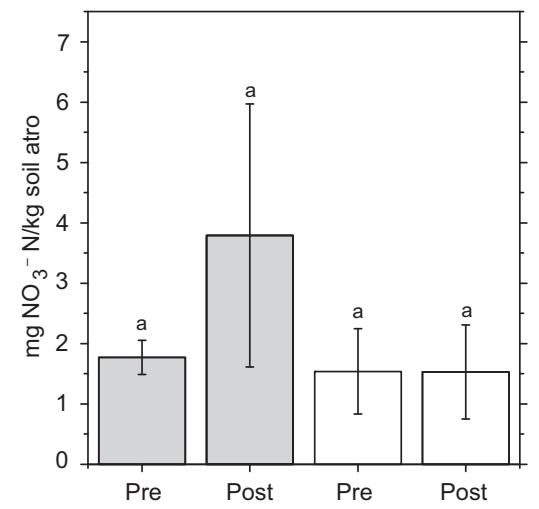

b

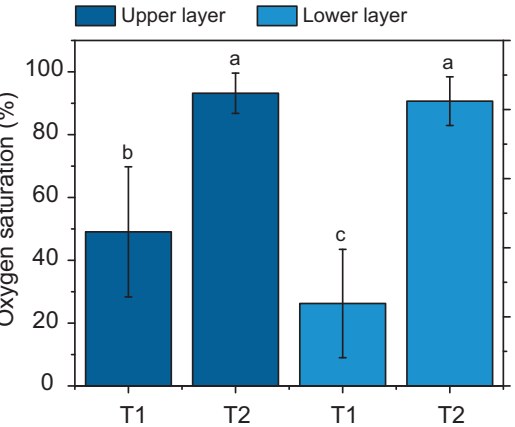

C
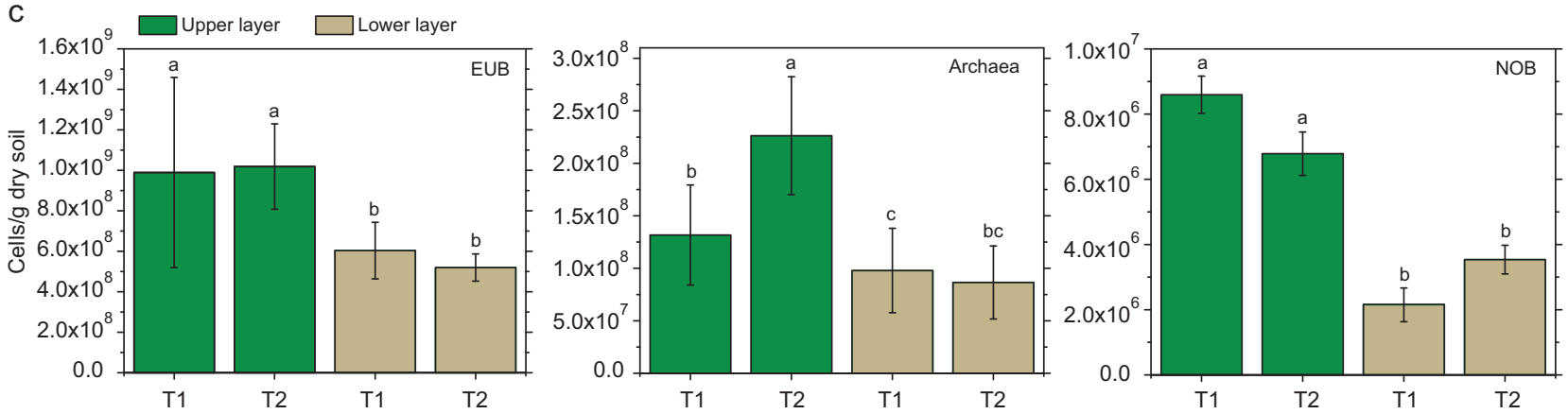

Fig. 3 Nutrient content, oxygen saturation, and cell numbers at varying sampling times and in different strata. a Nitrite and nitrate contents of control and methyl iodide $\left(\mathrm{CH}_{3} \mathrm{l}\right)$ treated samples before (pre) and after (post) a desiccation cycle. Error bars indicate standard deviation and different letters indicate significant differences (one-way ANOVA and post hoc tests, $p<0.01, n=3$ ); atro =absolutely dry. b Average oxygen saturation (\%) obtained at T1 (99\% WHC) and T2 (30\% WHC) in the upper (photoautotrophic layer; 0-400 $\mu \mathrm{m})$ and lower layer (heterotrophic layer; $>400-3000 \mu \mathrm{m}$ ) within biocrust samples. Bars represent mean values, error bars indicate standard deviation $(n=8)$. Results of two-way repeated measures ANOVA and post hoc tests $(p<0.05)$ are given as letters on top of bars. c Cell numbers of CARD-FISHstained bacteria (EUB), archaea and nitrite-oxidizing bacteria (NOB) per gram of soil detected at stage 1 and 2 during desiccation in the upper layer and lower layer of the biocrust. Bars represent mean values of 1000 cell counts on filter sections per biocrust samples. Error bars indicate standard deviation $(n=3)$. Results of Bayesian hierarchical model fitted to account for pseudoreplication (posterior probability $<0.05)$ are given as letters on top of bars.

encoding enzymes for $\mathrm{N}$ fixation, ammonification, nitrification, denitrification, anammox, dissimilatory nitrate reduction to ammonium (DNRA), and assimilatory nitrate reduction were detected (Fig. 4a). Hierarchical cluster analysis (Figs. S2, S3) and a nonmetric multidimensional scaling illustrated that the gene expression profiles differed clearly between the three stages during desiccation (Fig. 4b), with samples taken during the same stage being more similar than those taken during different stages. An analysis of similarity (ANOSIM) test supported the conclusion that the metabolic potential was statistically different between the three stages of desiccation (ANOSIM $r=0.876, p=0.003, n=3$, permutation $=9999$ ). The overlap of the detected probes between the samples is shown in Table S4 and S5.

Biocrust samples comprised a reservoir of transcripts (mRNA) involved in the major pathways of the $\mathrm{N}$ cycle, suggesting microbial contributions to the different $\mathrm{N}$ transformations (Fig. 4c). The number of mRNAs detected differed widely, ranging from 0 to $\sim 400$, with the highest numbers observed for nifH and particularly low numbers for genes encoding enzymes for nitrification and anammox (Fig. S4). During the desiccation cycle, we observed a rapid recovery of the metabolism, as at T1, 20-30 min after wetting, genes involved in all major $\mathrm{N}$-transforming processes were already induced (Fig. 4c, d). For most processes, the mRNA levels of functional genes showed an increase with time, except for anammox (Fig. 4c). For $\mathrm{N}$ fixation (nifH) and ammonification (ureC), there was a rather homogeneous increase in gene expression. Denitrification and assimilatory $\mathrm{N}$ reduction showed a stronger increase during the first phase (from T1 to T2), and DNRA during the second phase of the desiccation cycle (from T2 to T3) (Fig. 4d).

The number of $\mathrm{N}$-transforming species increased significantly from T1 to T2 (320 and 366 species) and from T2 to T3 (410 species; Fig. 4e). Also on higher taxonomic levels, this overall increase could be observed (Table S6). A large portion of the metabolically active bacteria during the desiccation cycle belonged to Alpha- and Gammaproteobacteria. The number of taxa involved in N-cycling in biocrusts was quite similar for a large range of bacterial families (ranging between $\sim 5$ and $\sim 15$ ) but there were also some families that provided large numbers of taxa, as e.g., Rhodobacteraceae, Bradyrhizobiaceae, Enterobacteriaceae, and Pseudomonadaceae (Fig. 4e).

The nifH genes, indicative of diazotrophic ability, were phylogenetically widespread, but particularly abundant among Euryarchaeota, Firmicutes, Cyanobacteria, and Alphaproteobacteria (Fig. 5). The onset of $\mathrm{N}$ fixation required more extended periods of recovery in Methanoregulaceae, Methanomicrobiaceae, Clostridiales, Desulfomicrobiaceae, and Rhodobacteraceae as compared to the other detected diazotrophs (Figs. 5, S5). Potential nitrification activity was attributed to the domain of Archaea and the class of Betaproteobacteria. The most abundant denitrifiers were concentrated within the phyla Bacteroidetes, Actinobacteria, and Proteobacteria. Ammonification genes were widely spread across the domains Archaea, Bacteria, and Eukarya, and highest values of signal intensity (for ureC), increasing during the desiccation cycle, were observed in 
a

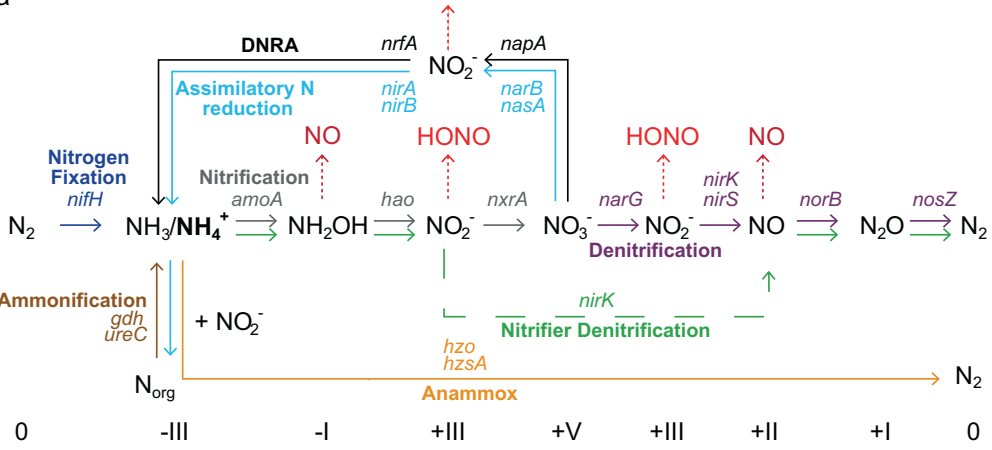

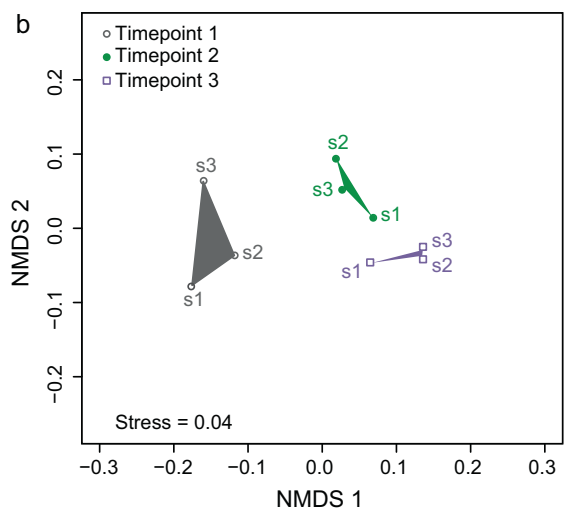

d

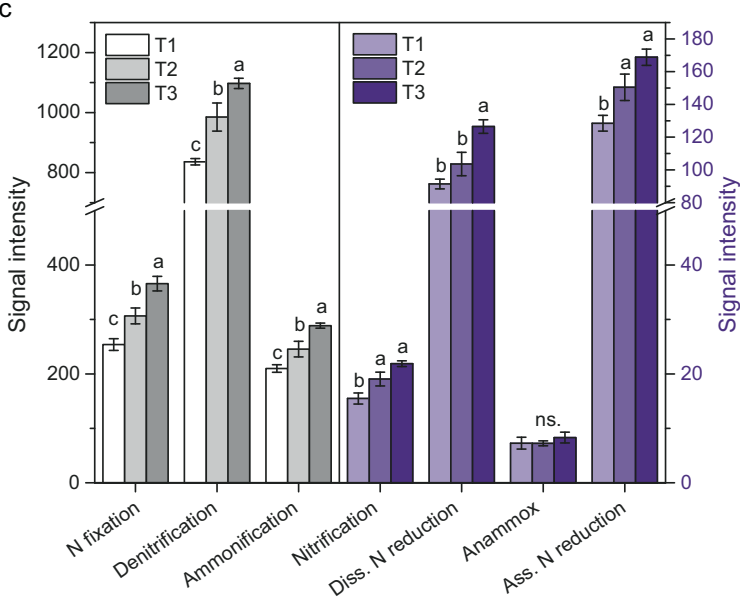

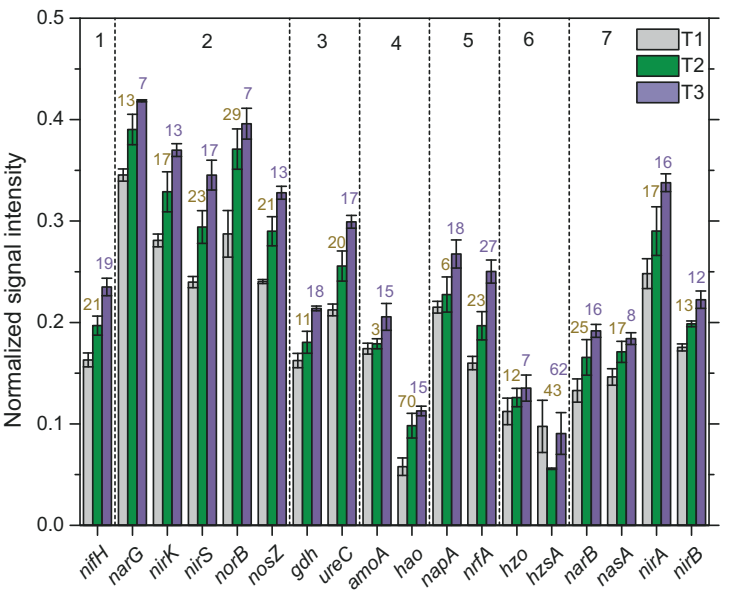

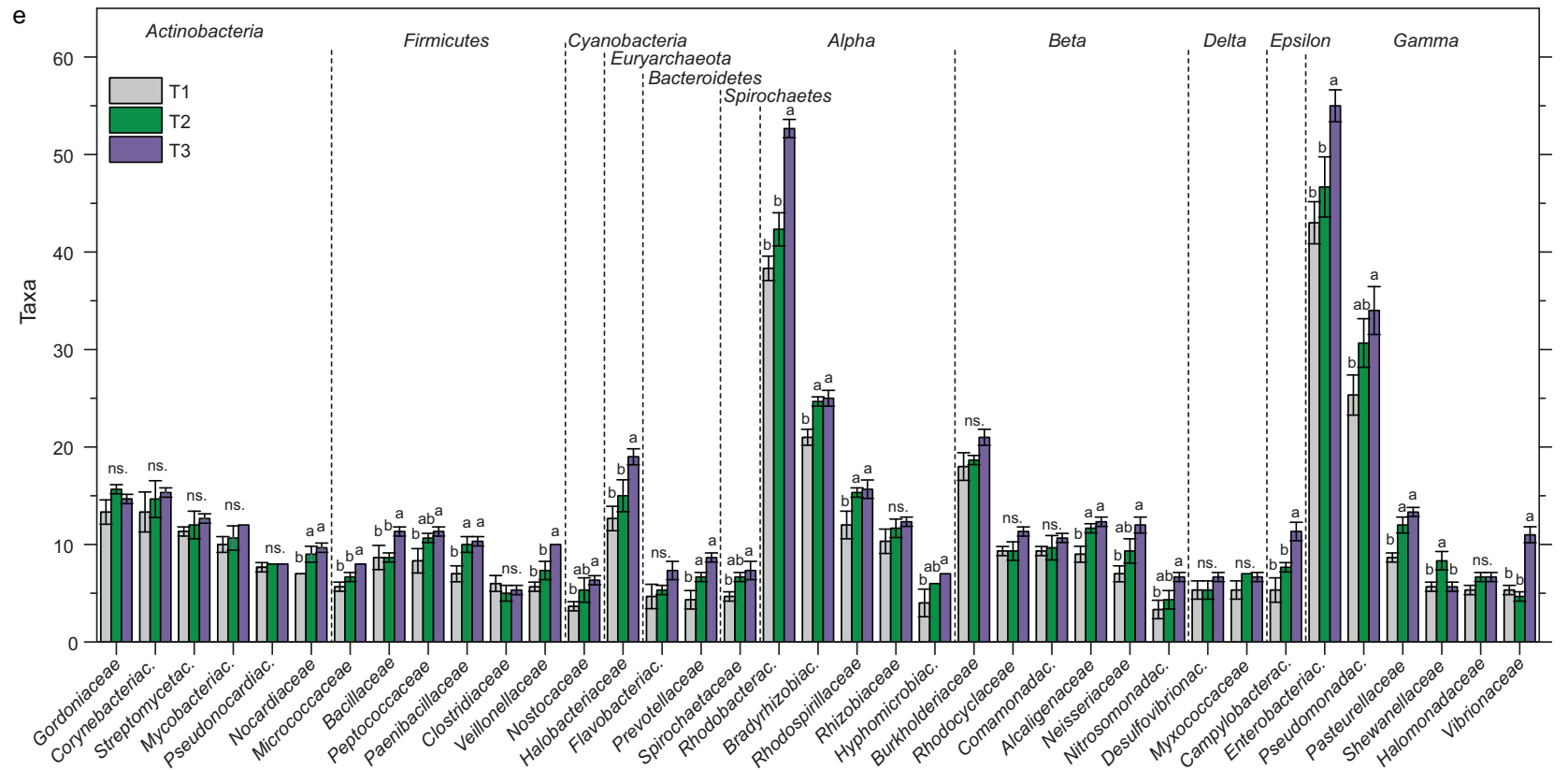

Fig. 4 Schematic representation of the $\mathbf{N}$ cycle and analyses of data from the functional gene microarray. a Biogeochemical $\mathrm{N}$ cycle: $\mathrm{N}$-transforming processes and encoding genes catalyzing $\mathrm{N}$-cycling reactions are shown (b-e) Functional gene microarray. b Nonmetric multidimensional scaling (NMDS) plot of Bray-Curtis similarities for the functional gene profiles identified at different stages during desiccation (c, d) Signal intensity per N-transforming process/gene detected at different stages of the desiccation cycle of biocrusts. Mean values of three replicates per stage during desiccation were plotted with the standard deviation. Differences between stages of desiccation were tested with a one-way ANOVA and labelled with lowercase letters. In (d) the signal intensity was normalized by the number of probes for each gene on the array. Numbers above bars at T2 show percentual increase between T1 and T2, those above bars at T3 show percentual increase between T2 and T3.1: N fixation; 2: Denitrification; 3: Ammonification; 4: Nitrification; 5: Dissimilatory N reduction; 6: Anammox; 7: Assimilatory $\mathrm{N}$ reduction (e) N-transforming microorganisms within the phyla Actinobacteria, Firmicutes, Cyanobacteria, Bacteroidetes, Spirochaetes, Euryarchaeota and in families within the phylum Proteobacteria. Families with $>5$ taxa were plotted. For full list of identified organisms, see Table S7. 


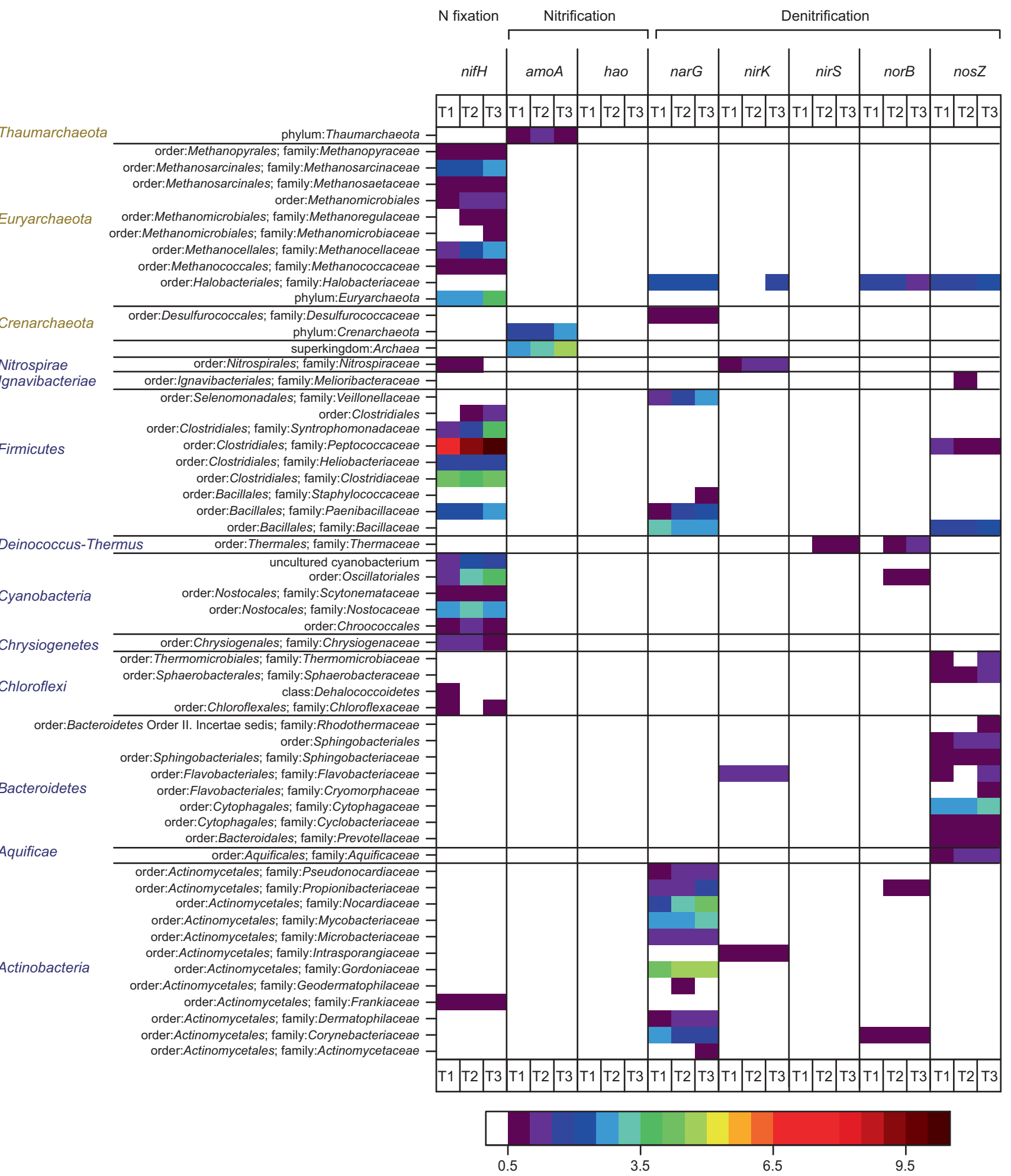

Fig. 5 Functional gene microarray. a, b Taxa-function relationship for N-cycling genes. Mean normalized signal intensity is shown. White color indicates non-detected signal, while intensity of positive signals is indicated from blue (lower signal intensities) to red color (higher signal intensities). Unclassified bacteria are not shown.

organisms affiliated with Rhodobacteraceae, Streptomycetaceae, and Enterobacteriaceae (Fig. S6).

The microarray profiles were compared to identify changes of gene expression over the course of the desiccation cycle. Of the 2569 tested probes, the transcript levels of 221 probes changed significantly during desiccation (Fig. 6a, c, e, g). Of these 221 probes, some were expressed in several stages, others were only detected at one point in time (expressed exclusively). Along with the increasing number of detected probes, 7 (3.2\%), $16(7.2 \%)$, and 79 probes (35.7\%) were only detected at $\mathrm{T} 1, \mathrm{~T} 2$, and $\mathrm{T} 3$, respectively (Fig. 6a, C, 


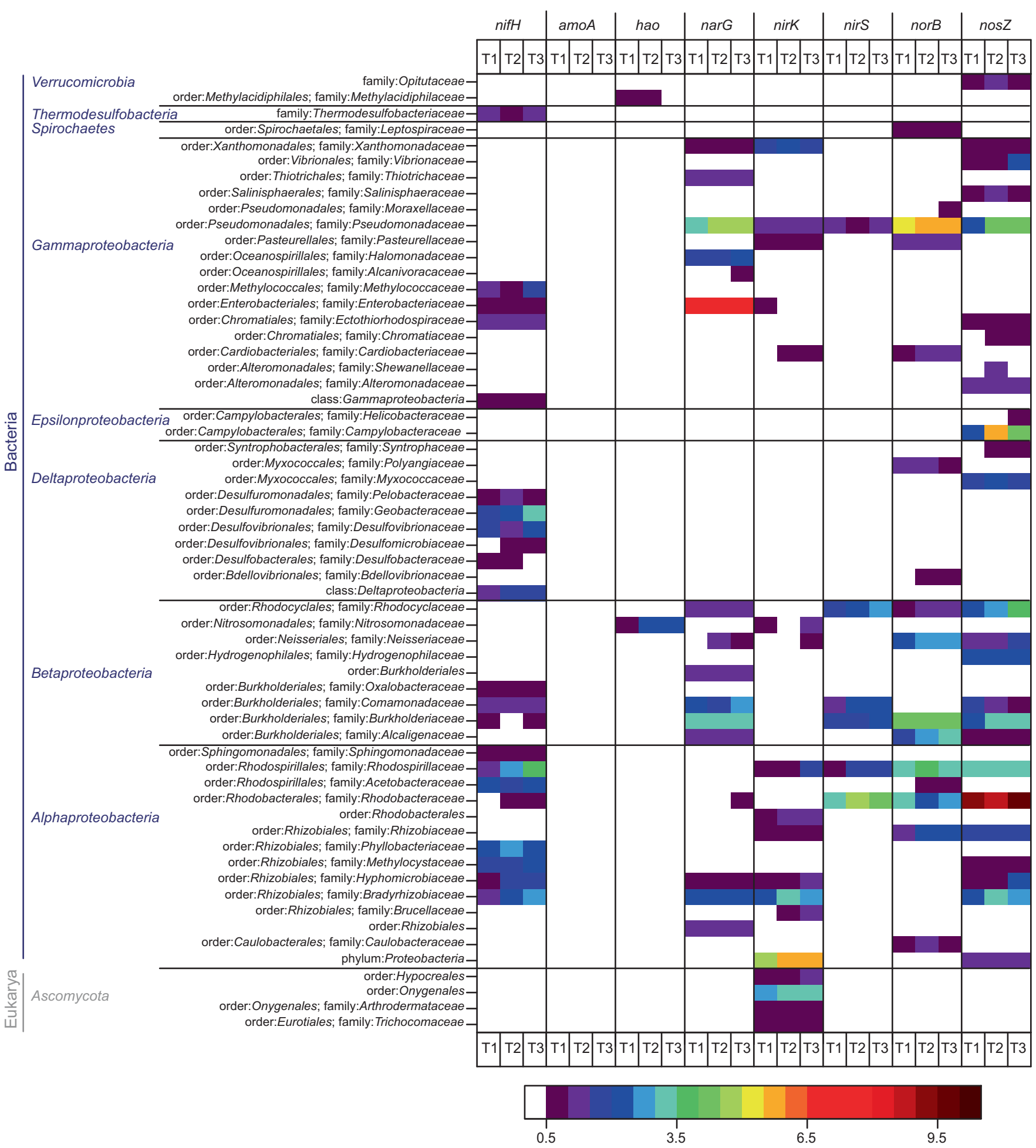

Fig. 5 (continued)

e). The analysis also revealed a strong overlap between the genes induced during $\mathrm{T} 2$ and $\mathrm{T} 3$, as 99 probes (44.8\%) were detected at T2 and T3 but not at T1 (Fig. $6 \mathrm{~g}$ ). Among genes, of which the expression was initiated at T3 (Fig. 6e) or T2 and T3 (Fig. 6g), there were probes coding for all studied $\mathrm{N}$-transforming processes. In contrast, no genes coding for $\mathrm{N}$ fixation, nitrification, and anammox were expressed exclusively at $\mathrm{T} 1$, and those coding for nitrification and $\mathrm{N}$ reduction processes were not expressed exclusively at T2 (Fig. 6a, c). Different bacterial families became active and the number of families tended to increase with progressing desiccation (Fig. 6b, d, f, h). Generally, at T1 
a
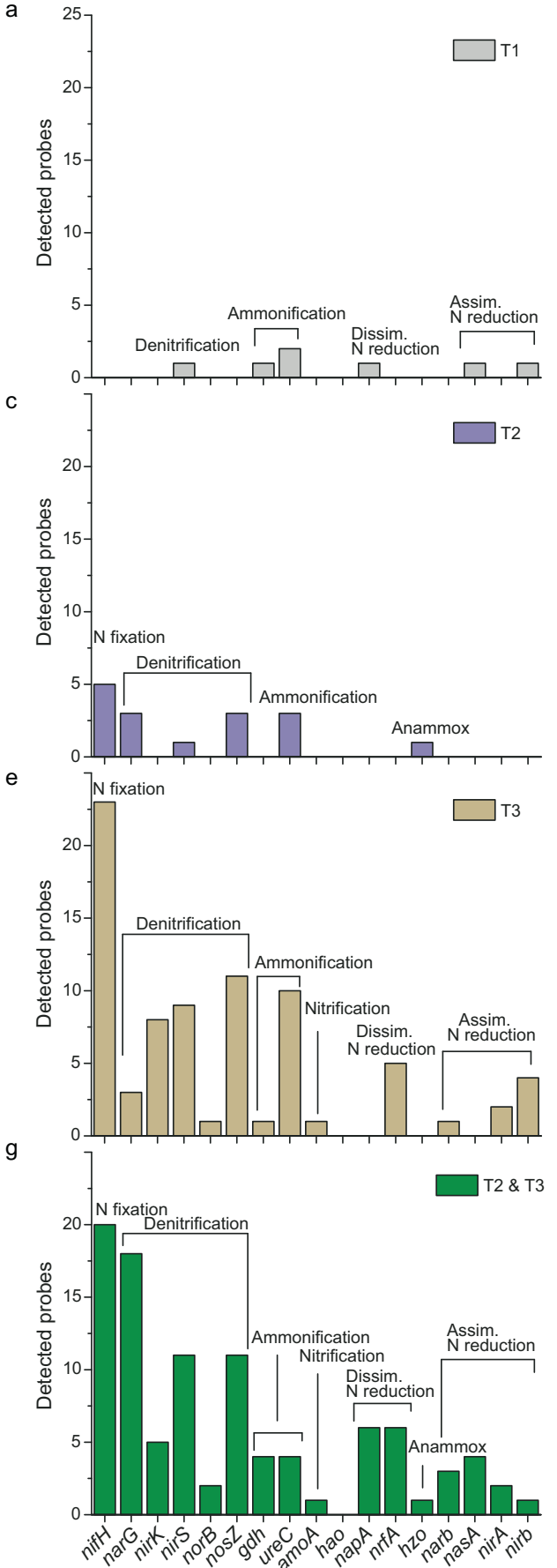

b
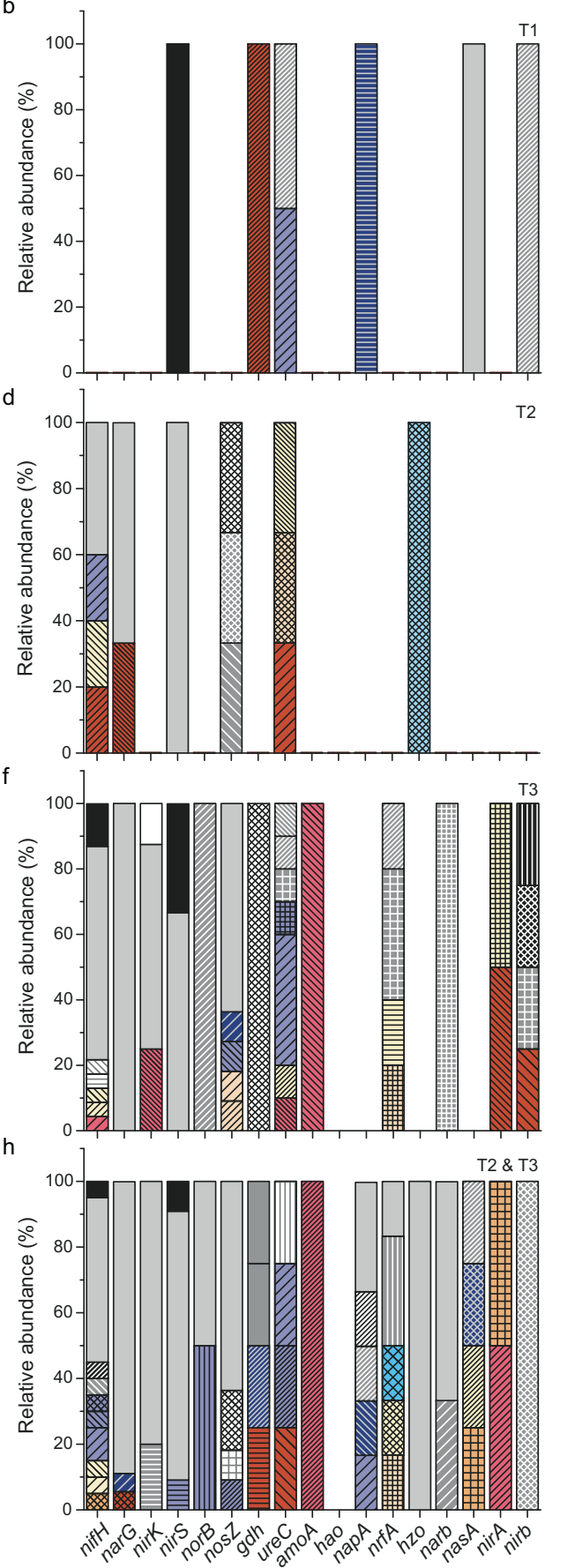
Protozoa
$\square$ order:Hypocreales
uncultured organisms III Methylacidiphilaceae Ver \begin{tabular}{l|l} 
IIIS Spirochaetaceae & Spi
\end{tabular} |Eps III Epsilonproteobacteria 17 Syntrophobacteraceae Syntrophaceae Myxococcaceae Geobacteraceae $\checkmark$ Shewanellaceae Pseudomonadaceae Pasteurellaceae Moraxellaceae Ectothiorhodospiraceae Chromatiaceae Cardiobacteriaceae
Alteromonadaceae \# Alernivoradaceae $\angle$ Rhocac Ohodocyclaceae Oxalobacteracea Burkholderiales Alcaligenaceae Rhodospirillaceae Rhodobacteraceae Rhizobiaceae Hyphomicrobiaceae Bradyrhizobiaceae Alphaproteobacteria Arder:Planctomycetales Lentisphaeraceae ales Pla x Veillonellaceae T\Syntrophomonadaceae \begin{tabular}{l|l}
72 & Ruminococcaceae \\
Peptococcaceae & Fir
\end{tabular} III Planococcaceae mLactobacillaceae Clostridiaceae (n) order:Chroococcales I Cya 7 Rhodothermaceae Mrevotellaceae W Blattabacteriaceae Propionibacteriaceae Nocardiaceae Micrococcaceae Gordoniaceae Geodermatophilaceae Frankiaceae Corynebacteriaceae Coriobacteriaceae Methanomicrobiaceae Halobacteriaceae \begin{tabular}{l|l} 
Archaeoglobaceae & Ar
\end{tabular}
Euk

Epi Del \begin{tabular}{|l|} 
\\
Gam \\
Bet \\
Alp \\
Pla \\
Len
\end{tabular} Fir Cya Bac Act Act $\mid$ Ar

Fig. 6 Functional gene microarray. a, c, e Number of probes per gene only detected at a T1, c T2, e T3, and $\mathbf{g}$ T2 and T3. b, d, f, h Taxonomic groups of the detected probes per gene at the family level detected at b T1, d T2, f T3, and $\mathbf{h}$ T2 and T3. Ar: Archaea; Act: Actinobacteria; Bac: Bacteroidetes; Cya: Cyanobacteria; Euk: Eukarya; Fir: Firmicutes; Len: Lentisphaerae; Pla: Planctomycetes; Alp: Alphaproteobacteria; Bet: Betaproteobacteria; Gam: Gammaproteobacteria; Del: Deltaproteobacteria; Eps: Epsilonproteobacteria; Spi: Spirochaetes; Ver: Verrucomicrobia. N fixation: nitrogen fixation; dissim. $\mathrm{N}$ reduction: dissimilatory nitrate reduction; assim. $\mathrm{N}$ reduction: assimilatory nitrate reduction.

there were only few uniquely detected bacterial families, whereas towards T2 and T3 the taxonomic diversity showed a substantial increase.

\section{Proteomic response to desiccation stress}

A total of 60,42 , and 44 protein groups were identified for $\mathrm{T} 1, \mathrm{~T} 2$, and $\mathrm{T} 3$, respectively. There was a greater overlap in shared proteins between T1 and T2 (18.6\%) as compared to T2 and T3 (3.4\%), whereas $6.4 \%$ of the proteins were shared between all three stages (Fig. S7a).
When considering the leading proteins, with the highest number of identified peptides, $88 \%$ of the identified proteins were assigned to bacterial species (mainly Cyanobacteria and Alphaproteobacteria), while the remaining proteins originated from eukaryotes (fungi and protists) (Supplementary Material 2). Proteins were grouped into categories based on gene ontology terms. The majority of the identified protein groups was related to ATP synthesis, photosynthesis, protein biosynthesis, and stress response (Fig. S7b-e). Some categories, such as ATP synthesis, carbohydrate metabolism, and protein biosynthesis 
1020

were less represented in the samples of $\mathrm{T} 3$ compared to $\mathrm{T} 1$ and $\mathrm{T} 2$, whereas the number of protein groups involved in fatty acid metabolism and photosynthesis was higher at T3. Protein groups linked to stress response, such as chaperones that are produced during stress conditions e.g., desiccation, occurred in larger numbers at T1 and T3 compared to T2 (Fig. S7). The identified proteins and their taxonomic classifications are given in the Supplementary Material 2. Proteins associated with $\mathrm{N}$ transformations could not be identified.

\section{DISCUSSION \\ Effect of soil moisture and mineral nitrogen content on $\mathrm{N}_{\mathrm{r}}$ emissions}

At high water contents, nearly no HONO and $\mathrm{NO}$ emissions could be determined (Fig. 2a). Starting between $70 \%$ and $80 \%$ WHC, emissions increased, first in a linear and then in an exponential manner. Maximum fluxes of $71.8 \pm 14 \mathrm{ng} \mathrm{m}^{-2} \mathrm{~s}^{-1}$ of HONO-N and $153.5 \pm 28.6 \mathrm{ng} \mathrm{m}^{-2} \mathrm{~s}^{-1}$ of NO-N were observed at $\sim 20 \% \mathrm{WHC}$ (Fig. 2a). Similar emission ranges of HONO-N and NO-N from soil, ranging between 2-260 ng m $\mathrm{m}^{-2} \mathrm{~s}^{-1}$ and 2-135 $\mathrm{ng} \mathrm{m}^{-2} \mathrm{~s}^{-1}$, respectively, at WHC values between $\sim 0 \%$ and $40 \%$ have been previously reported [23]. Arid and semi-arid soils were observed to emit NO-N ranging from 1.2 to $142 \mathrm{ng} \mathrm{m}^{-2} \mathrm{~s}^{-1}$ at optimum soil moisture conditions [50]. In an earlier study, biocrusts from South Africa released similar $\mathrm{NO}$ and $\mathrm{HONO}$ emission fluxes with maximum values at $20-25 \%$ WHC [25]. Maximum HONO-N and NO-N fluxes of $27.1 \pm 16.1$ and $26.5 \pm 15.9 \mathrm{ng} \mathrm{m}^{-2} \mathrm{~s}^{-1}$, respectively, for cyanobacteria-dominated biocrusts from the Mediterranean island of Cyprus were measured at $17-33 \%$ WHC [26]. Thus, the emission patterns and rates observed in this study are consistent with previously reported data.

Measurements of soil $\mathrm{N}$ revealed a significantly higher $\mathrm{NO}_{2}{ }^{-}-\mathrm{N}$ content after a full desiccation cycle, and the $\mathrm{NO}_{3}{ }^{-} \mathrm{N}$ content showed a similar trend, whereas for $\mathrm{CH}_{3} \mathrm{l}$ treated biocrust samples the desiccation cycle had no substantial effect on $\mathrm{NO}_{2}{ }^{-}$and $\mathrm{NO}_{3}{ }^{-}$ production, most likely due to suppressed microbial activity (Fig. 3a). These results are in line with findings of a previous study, reporting a continuous $\mathrm{NO}_{2}^{-}$accumulation for a dryland soil over the course of drying [51]. Su et al. [22] were one of the first who described that soil $\mathrm{NO}_{2}{ }^{-}$can serve as a strong source of atmospheric HONO and that fertilized soils with high $\mathrm{HONO}^{*}$ and low $\mathrm{pH}$ (given the same $\mathrm{NO}_{2}{ }^{-}$ content) appear to be particularly strong sources of $\mathrm{HONO}$ and $\mathrm{OH}$. The fluxes of HONO and NO have been shown to decrease by $~ 75 \%$ for soil treated with $\mathrm{CH}_{3} \mathrm{l}$ compared to untreated soil [23], which was concomitant with a $92 \%$ decrease in the ATP content, used as an indicator for microbial activity. The addition of the nitrification inhibitor thiourea $\left(\mathrm{CH}_{4} \mathrm{~N}_{2} \mathrm{~S}\right)$ blocked the oxidation of $\mathrm{NH}_{4}^{+}$to $\mathrm{NO}_{2}$ and $\mathrm{NO}_{3}{ }^{-}$in soils and caused decreased $\mathrm{HONO}$ emissions from upland soils [29]. Similarly, NO and HONO emissions of autoclaved dark cyanobacteria-dominated biocrusts from South Africa clearly declined as a result of sterilization [25]. Thus, our results suggest, coherently with previous studies, that microorganisms are responsible for the production of $\mathrm{NO}_{2}{ }^{-}$and increased emission rates of $\mathrm{NO}$ and HONO.

The observed accumulation of $\mathrm{NO}_{2}{ }^{-}$(and a similar trend for $\mathrm{NO}_{3}{ }^{-}$) in untreated biocrust samples during a desiccation cycle (Fig. 3a) could be caused by an imbalance in the rates of its production and consumption during localized $\mathrm{N}$ cycling processes, i.e., nitrification, denitrification, assimilatory $\mathrm{N}$ reduction, DNRA, and anammox occurring simultaneously in microenvironments. For $\mathrm{NO}_{2}{ }^{-}$to accumulate during nitrification, this would mean that the $\mathrm{NH}_{3}$ oxidizing activity is stimulated and/or the $\mathrm{NO}_{2}{ }^{-}$-oxidizing (and $\mathrm{NO}_{3}{ }^{-}$ reducing) activity is limited relative to the $\mathrm{NH}_{3}$-oxidizing potential. This can be caused by an inhibition of $\mathrm{NO}_{2}{ }^{-}$-oxidizing bacteria by high soil $\mathrm{pH}$ and/or high concentration of free $\mathrm{NH}_{3}$ and $\mathrm{HNO}_{2}$ during nitrification $[52,53]$. In non-cropped Oregon soils, $\mathrm{NO}_{2}{ }^{-}$accumulation caused by $A O A$ and $A O B$ occurred within $6 \mathrm{~h}$ after wetting to field capacity and persisted over $48 \mathrm{~h}$, whereas $\mathrm{NO}_{3}{ }^{-}$accumulation increased over time. Upon the addition of Nitrobacter vulgaris, a $\mathrm{NOB}$, to the soil slurry, $\mathrm{NO}_{2}{ }^{-}$accumulation was inhibited and $\mathrm{NO}_{3}{ }^{-}$ accumulation increased, while the overall rate of nitrification was unaffected [54]. It is known that $A O B$ retain their ammonia oxidation capacity after long-term $\mathrm{NH}_{4}{ }^{+}$starvation [55-58], whereas Nitrobacter winogradskyi, belonging to $\mathrm{NOB}$, lost $80 \%$ of the $\mathrm{NO}_{2}{ }^{-}$-oxidizing capacity after $\mathrm{NO}_{2}{ }^{-}$deprivation for six days. Accumulation of $\mathrm{NO}_{2}{ }^{-}$ could also happen during denitrification, and here several factors are involved in the process. Differential repression of nitrite and nitrate reductases, the competition for electron donors between nitrite and nitrate reductases, as well as $\mathrm{pH}$ values, $\mathrm{O}_{2}$ and $\mathrm{NO}_{3}{ }^{-}$concentrations, and utilisable $\mathrm{C}$ influence a potential $\mathrm{NO}_{2}{ }^{-}$accumulation during denitrification $[59,60]$. Such a difference in the overall process rates may explain a $\mathrm{NO}_{2}^{-}$(and $\mathrm{NO}_{3}{ }^{-}$) accumulation in soil and biocrusts over the course of a desiccation cycle.

\section{Nitrogen-transforming microorganisms}

The potential for N-transforming processes, represented by mRNA transcripts $[47,48]$, increased over the course of the desiccation cycle (Figs. 4c, d; S4). The nifH genes, indicative of diazotrophic ability, were widespread, but particularly abundant among Euryarchaeota, Cyanobacteria, Firmicutes, and Alphaproteobacteria (Fig. 5). These results illustrate, that $\mathrm{N}$ fixation in biocrusts was not solely accomplished by diazotrophic cyanobacteria, but also by various other bacteria and archaea, corroborating previous observations [61, 62].

Potential nitrification was attributed to Archaea and Betaproteobacteria, but the number of probes with positive hybridization signals and the overall signal intensity was relatively low when compared to the other processes, as N fixation and denitrification. Similarly low signal intensities were observed in a previous study $[63,64]$, where the same method (Geochip 5.0) was applied, whereas in other studies on biocrusts the potential activity of nitrification enzymes was similarly high as that of $\mathrm{N}$ fixation and denitrification enzymes [65]. Thus, it seems that the probes for key nitrification genes of the FGA do not cover a significant part of potential nitrifiers in biocrusts. Aerobic ammonia-oxidizing organisms occur in phylogenetically coherent groups within the Beta- but also Gammaproteobacteria (genera Nitrosospira, Nitrosomonas, and Nitrosococcus) and in the Archaea $[66,67]$. Furthermore, for nitrifiers it has been shown, that also small populations can be very important in $\mathrm{N}$ transformations, due to their high substrate requirements, resulting in large quantities of intermediates and the end product $\mathrm{NO}_{3}{ }^{-}$[68].

Denitrifiers were broadly distributed across soil bacteria with Bacteroidetes, Actinobacteria, and Proteobacteria as most abundant phyla (Fig. 5). This is in line with the literature, describing representatives of $>60$ genera of the domains of Bacteria and Archaea, as well as some eukaryotes as denitrifiers [66, 67]. A significant fraction of genes involved in denitrification and $\mathrm{N}$ fixation were assigned to unclassified bacteria, which was also observed in a previous study [64].

Proteins from genes associated with $\mathrm{N}$ transformations could not be detected with the current approach (Fig. S7). This could be caused by a general problem impeding proteome approaches, like (i) difficulty to detect low-abundance proteins, as their detection is obscured by highly expressed proteins (e.g., ATP synthases), (ii) difficulty to identify proteins within complex environments such as soils, and (iii) poor protein extraction efficiency from soil [6972]. Nevertheless, at T1 and T3, more chaperones were detected than at T2, and more proteins involved in the fatty acid metabolism occurred at $\mathrm{T} 3$ than at $\mathrm{T} 2$, presumably reflecting the need for the community to cope with shifts in moisture conditions [73-75]. Bacteria exposed to fluctuations in water status are capable of modifying the cell membrane. The upregulation of shock-response genes, including those encoding molecular chaperones are associated with xerotolerance in bacteria [74]. The observed drop in ATP and protein biosynthesis at T3 might 
indicate that microorganisms enter a reversible form of dormancy, a common response of bacteria to abiotic stress $[74,76]$.

\section{Timing and water dependency of microbial activity}

In the current study, we observed that already shortly after wetting of the biocrusts, the conditions became favourable for microbial metabolism. As early as $30 \mathrm{~min}$ upon wetting, significant amounts of mRNA transcripts of genes involved in the major pathways of the $\mathrm{N}$ cycle, including $\mathrm{N}$ fixation, denitrification, and nitrification, were detectable, suggesting that the organisms and possibly enzyme activity persist during dry periods in soil (Fig. 4c, d).

We observed an increase in the number of microbial taxa becoming active along a desiccation cycle as well as a sequence of different microbial taxa contributing to various $\mathrm{N}$-transforming processes (Figs. 4e, 5, 6). These results are consistent with previous studies investigating the response of soil bacteria to desiccation events [77-79]. Within two hours after rewetting, the soil bacterial community (rRNA-based) returned to pre-dry community composition [79]. Furthermore, upon rewetting, transcript copies of bacterial $r p o B$ genes encoding a subunit of bacterial RNA polymerase increased, indicating rapid resumption of transcriptional activity [79]. In these studies, bacteria responding rapidly to wetting have been linked to $\mathrm{CO}_{2}$ emissions. Most bacteria displayed their highest activity $15 \mathrm{~min}$ to one hour after wetting [78]. Such a "respiration burst" and a quick bacterial response upon wetting events has also been described for biocrust environments [80-82]. Denitrification in cyanobacteriadominated crusts from the Sultanate of Oman started within two hours under wet and anaerobic conditions [83].

Already shortly after rewetting (at $\mathrm{T} 1$ ), $\mathrm{AOB}$ and $\mathrm{AOA}$ were active, suggesting that a longer dry spell (likely accompanied by a starvation of the microorganisms) did not have a major effect on the ammonia oxidation capacity (Figs. 4d, 5). Similar observations were made in a previous work, showing an increase in transcripts of the bacterial amoA genes within one hour and of archaeal amoA within nine hours after water addition [55]. However, one also has to bear in mind that a diffusion limitation of $\mathrm{O}_{2}$ at high water contents has a profound effect on the physiology of ammonia-oxidizing microorganisms [37]. Under oxic conditions, nitrification occurs in an unhampered way through the activity of $A O B / A O A$ and NOB [84]. Under $\mathrm{O}_{2}$ limitation, however, $\mathrm{AOB}$ can undergo physiological changes, e.g. by inducing nitrifier denitrification, which may cause a release of NO. Besides the key enzyme ammonia monooxygenase (AMO), most AOB have a nitrite reductase, NirK, which is necessary for efficient ammonia oxidation at atmospheric $\mathrm{O}_{2}$ levels and involved but not essential for NO production during nitrifier denitrification [84]. The transcription of nirk (nitrite reductase-encoding gene) was lower during $\mathrm{O}_{2}-$ limited conditions in Nitrosomonadaceae and was upregulated at $\mathrm{T} 3$, likely as a result of higher $\mathrm{NO}_{2}^{-}$concentrations, indicating efficient ammonia oxidation (Fig. 5). These gene expression patterns are consistent with previous observations [84].

The expression of archaeal $a m o A$ and the increased number of archaea, quantified by means of CARD-FISH at T2 (Fig. 3c), could contribute to nitrite accumulation around $\mathrm{T} 2$. The increase in cell numbers is likely caused by growth, as archaea are supposed to have rapid reproduction times (often below $1 \mathrm{~h}$ ) [85]. Molecular studies indicate that AOA often outnumber nitrifying bacteria in marine [86] and terrestrial ecosystems [87, 88], and there are indications that $A O A$ also contribute to nitrification in seasonally dry ecosystems $[89,90]$.

Besides nitrification, also microbial $\mathrm{NO}_{3}{ }^{-}$reduction processes may be relevant. We found genes encoding denitrification, assimilatory $\mathrm{N}$ reduction, and DNRA in substantial quantities, while anammox was hardly observed (Fig. 4C), in coherence to former biocrust studies [64, 91]. The expression of narG, nirk, nirS, norB, and nosZ was considerably higher than for other functional genes, suggesting that denitrification may play a prominent role in reduction processes, and thus in the HONO and $\mathrm{NO}$ emissions from biocrusts. There was a substantial increase in narG, nirk, nirS, norB, and nos $Z$ expression between $\mathrm{T} 1$ and $\mathrm{T} 2$, which was by far lower between T2 and T3, indicating that denitrifier activity may have been particularly strong before maximum HONO- and NO-emissions (Fig. $4 \mathrm{~d}$ ). In addition, the emission of HONO and NO has been suggested to be linked to a strongly localized pronounced drop in $\mathrm{pH}$, and denitrifiers are hampered by $\mathrm{O}_{2}$ availability over the course of drying [37]. The synthesis of denitrification enzymes has been shown to be controlled by $\mathrm{O}_{2}$ levels, with $\mathrm{NO}_{2}{ }^{-}$reduction as the most sensitive step during denitrification $[52,92]$. Our gene expression analyses showed that narG expression (responsible for $\mathrm{NO}_{3}{ }^{-}$reduction) within the families Nocardiaceae, Pseudomonadaceae, Enterobacteriaceae, and Burkholderiaceae was considerably higher at T3 than $\mathrm{T} 2$ or remained more or less unchanged at T2 and T3 for Gordoniaceae (Fig. 5). On the contrary, expression levels of the nirK and nirS genes (responsible for $\mathrm{NO}_{2}{ }^{-}$reduction) were lower than for narG (Pseudomonadaceae, Burkholderiaceae) or no transcription could be detected during drying (e.g., Nocardiaceae, Enterobacteriaceae, Gordoniaceae, Desulfurococcaceae, Veillonellaceae, Paenibacillaceae, Bacillaceae, Pseudonocardiaceae, Propionibacteriaceae, Mycobacteriaceae) (Fig. 5). These results suggest that differences in the expression of nitrate and nitrite reductases during the shift from $\mathrm{O}_{2}$-limited to aerobic conditions in the course of drying as well as high $\mathrm{NO}_{3}{ }^{-}-\mathrm{N}$ contents likely contribute to accumulation of $\mathrm{NO}_{2}{ }^{-}$, which is relevant for $\mathrm{HONO}$ and $\mathrm{NO}$ emission fluxes from biocrusts and likely also from soils. In other studies, high concentrations of $\mathrm{NO}_{3}{ }^{-}$, free $\mathrm{NH}_{3}$, and $\mathrm{HNO}_{2}$ were found to have an inhibitory effect on $\mathrm{NO}_{2}{ }^{-}$reduction [92]. In the literature, the role of denitrification in biocrusts has been considered differently, ranging from largely irrelevant [91] to highly relevant [64, 83]. For HONO emissions from agricultural soils, Bhattarai and coauthors recently identified denitrification as the major pathway [40].

The $\mathrm{N}_{\mathrm{r}}$ measurements had to be carried out in the dark to avoid photochemical reactions. This has to be considered when interpreting the results. In other studies, it was shown that photosynthesis and respiration in illuminated cyanobacterial biocrusts recovered within minutes after water addition resulting in the formation of disparate oxygen microenvironments ranging from oxygen-supersaturated zones close to the surface to anoxic zones at $1-3 \mathrm{~mm}$ depth. Photosynthetic activity also affected the $\mathrm{pH}$ gradients in the biocrust. Local $\mathrm{pH}$ values up to 10.5 due to photosynthesis were measured, which may have consequences for the $\mathrm{N}_{\mathrm{r}}$ emission patterns $[93,94]$.

The observed increase in transcript levels at T3 (Fig. 4c, d) might indicate that microorganisms remain in a state, enabling a rapid recovery when conditions become favourable for growth. Comparing transcript profiles of growing cells and substrate-deprived bacterial cells, it was observed that transcript levels of some genes, like amoCAB (Nitrosomonas europaea) or genes involved in metabolic pathways (Mycobacterium tuberculosis) did not change significantly under growth or starved conditions. Hence, the strategy to cope with periods of starvation appears to include maintenance of mRNA of key enzymes, like nitrification genes. This may allow a rapid recovery when substrate becomes available [56, 57, 95, 96]. A graphical representation of the temporal connection between microbial metabolic activity and the emissions of HONO and NO during desiccation is shown in Fig. S8.

The physicochemical and structural characteristics of the soil environment create microenvironments differing in soil hydration conditions, gas/liquid diffusion, and nutrient availability, causing a heterogeneous, patchy distribution of microbes in the soil $[22,97-$ 102]. Moisture patchiness can result in aerobic and anaerobic microsites in close proximity, allowing different $\mathrm{N}$-transformations to occur next to each other [103]. This patchy distribution of organisms and processes likely has a pronounced impact on rates and patterns of biogeochemical processes, like the emission of NO 
and HONO from biocrusts and soil, which needs to be investigated by studies on the microscale.

\section{CONCLUSIONS}

Trace gas emission measurements over a desiccation cycle were linked to FGA, CARD-FISH, and soil analyses to obtain a deeper understanding of the biological processes involved in the observed $\mathrm{N}_{\mathrm{r}}$ gas emissions. Our data illustrated that organisms involved in all major $\mathrm{N}$-cycling processes became metabolically active within 30 min after wetting. The soil $\mathrm{N}$ content analyses showed a significant increase in $\mathrm{NO}_{2}{ }^{-}$-content, which likely served as a precursor for $\mathrm{HONO}$ and $\mathrm{NO}$ emissions peaking at relatively low water contents around $20 \% \mathrm{WHC}$. This is likely caused by a differential $\mathrm{O}_{2}$-dependent expression of nitrite as compared to nitrate reductase encoding genes during maximum HONO and NO emissions. Besides this, physiological responses in $A O B$ (nitrification at atmospheric $\mathrm{O}_{2}$-levels, nitrifier denitrification under $\mathrm{O}_{2}$-limited conditions), and growth and transcriptional activity of AOA during the transition from $\mathrm{O}_{2}$-limited to oxic conditions, might contribute to the release of HONO and NO. Thus, our data suggest that AOA are major contributors to ammonia oxidation in biocrusts, and a differential expression of denitrification genes during drying causes an accumulation of $\mathrm{NO}_{2}{ }^{-}$, serving as a precursor for HONO and NO emissions.

\section{REFERENCES}

1. Bahram M, Hildebrand F, Forslund SK, Anderson JL, Soudzilovskaia NA, Bodegom PM, et al. Structure and function of the global topsoil microbiome. Nature. 2018;560:233-7.

2. Bardgett RD, van der Putten WH. Belowground biodiversity and ecosystem functioning. Nature. 2014;515:505-11.

3. Falkowski PG, Fenchel T, Delong EF. The microbial engines that drive Earth's biogeochemical cycles. Science. 2008;320:1034-9.

4. Pointing SB, Belnap J. Microbial colonization and controls in dryland systems. Nat Rev Microbiol. 2012;10:551-62.

5. Belnap J, Weber B, Büdel B. Biological soil crusts as an organizing principle in drylands. In: Weber B, Büdel B, Belnap J, editors. Biological soil crusts: An organizing principle in drylands Ecological Studies 226. Cham: Springer International Publishing; 2016. p. 3-13.

6. Bowker MA, Reed SC, Maestre FT, Eldridge DJ. Biocrusts: the living skin of the earth. Plant Soil. 2018;429:1-7.

7. Maestre FT, Bowker MA, Cantón Y, Castillo-Monroy AP, Cortina J, Escolar C, et al. Ecology and functional roles of biological soil crusts in semi-arid ecosystems of Spain. J Arid Environ. 2011;75:1282-91.

8. Maier S, Tamm A, Wu D, Caesar J, Grube M, Weber B. Photoautotrophic organisms control microbial abundance, diversity, and physiology in different types of biological soil crusts. Isme J. 2018;12:1032-46.

9. Rodriguez-Caballero E, Belnap J, Büdel B, Crutzen PJ, Andreae MO, Pöschl U, et al. Dryland photoautotrophic soil surface communities endangered by global change. Nat Geosci. 2018;11:185-9.

10. Elbert W, Weber B, Burrows S, Steinkamp J, Budel B, Andreae MO, et al. Contribution of cryptogamic covers to the global cycles of carbon and nitrogen. Nat Geosci. 2012;5:459-62.

11. Kuypers MMM, Marchant HK, Kartal B. The microbial nitrogen-cycling network. Nat Rev Microbiol. 2018;16:263-76.

12. Crutzen PJ. The Role of $\mathrm{NO}$ and $\mathrm{NO}_{2}$ in the chemistry of the troposphere and stratosphere. Annu Rev Earth Planet Sci. 1979;7:443-72.

13. Shoemaker JK, Schrag DP, Molina MJ, Ramanathan V. What role for short-lived climate pollutants in mitigation policy? Science. 2013;342:1323-4.

14. Chameides WL, Fehsenfeld F, Rodgers MO, Cardelino C, Martinez J, Parrish D, et al. Ozone precursor relationships in the ambient atmosphere. J Geophys Res Atmos. 1992;97:6037-55.

15. Logan JA. Nitrogen oxides in the troposphere: Global and regional budgets. J Geophys Res Atmos. 1983;88:10785-807.

16. Crutzen PJ, Zimmermann PH. The changing photochemistry of the troposphere. Tellus A. 1991;43:136-51.

17. Finlayson-Pitts $B J$, Wingen LM, Sumner AL, Syomin D, Ramazan KA. The heterogeneous hydrolysis of $\mathrm{NO}_{2}$ in laboratory systems and in outdoor and indoor atmospheres: an integrated mechanism. Phys Chem Chem Phys. 2003;5:223-42.
18. Zhou X, Gao H, He Y, Huang G, Bertman SB, Civerolo K, et al. Nitric acid photolysis on surfaces in low- $\mathrm{NO}_{x}$ environments: significant atmospheric implications. Geophys Res Lett. 2003;30:2217.

19. Stemmler K, Ammann M, Donders C, Kleffmann J, George C. Photosensitized reduction of nitrogen dioxide on humic acid as a source of nitrous acid. Nature. 2006;440:195-8.

20. Kleffmann J. Daytime sources of nitrous acid (HONO) in the atmospheric boundary layer. Chem Phys Chem. 2007;8:1137-44.

21. Su H, Cheng YF, Shao M, Gao DF, Yu ZY, Zeng LM, et al. Nitrous acid (HONO) and its daytime sources at a rural site during the 2004 PRIDE-PRD experiment in China. J Geophys Res Atmos. 2008;113:D14.

22. Su H, Cheng YF, Oswald R, Behrendt T, Trebs I, Meixner FX, et al. Soil nitrite as a source of atmospheric HONO and $\mathrm{OH}$ radicals. Science. 2011;333:1616-8.

23. Oswald R, Behrendt T, Ermel M, Wu D, Su H, Cheng $Y$, et al. HONO emissions from soil bacteria as a major source of atmospheric reactive nitrogen. Science. 2013;341:1233-5.

24. Oswald R, Ermel M, Hens K, Novelli A, Ouwersloot HG, Paasonen $P$, et al. A comparison of HONO budgets for two measurement heights at a field station within the boreal forest in Finland. Atmos Chem Phys. 2015;15:799-813.

25. Weber B, Wu D, Tamm A, Ruckteschler N, Rodríguez-Caballero E, Steinkamp J, et al. Biological soil crusts accelerate the nitrogen cycle through large NO and HONO emissions in drylands. Proc Natl Acad Sci USA. 2015;112:15384-9.

26. Meusel H, Tamm A, Kuhn U, Wu D, Leifke AL, Fiedler S, et al. Emission of nitrous acid from soil and biological soil crusts represents an important source of HONO in the remote atmosphere in Cyprus. Atmos Chem Phys. 2018;18:799-813.

27. Meusel H, Kuhn U, Reiffs A, Mallik C, Harder H, Martinez M, et al. Daytime formation of nitrous acid at a coastal remote site in Cyprus indicating a common ground source of atmospheric HONO and NO. Atmos Chem Phys. 2016;16:14475-93.

28. Mamtimin B, Meixner FX, Behrendt T, Badawy M, Wagner T. The contribution of soil biogenic $\mathrm{NO}$ and $\mathrm{HONO}$ emissions from a managed hyperarid ecosystem to the regional $\mathrm{NO}_{\mathrm{x}}$ emissions during growing season. Atmos Chem Phys. 2016;16:10175-94.

29. Kubota M, Asami T. Source of nitrous acid volatilized from upland soils. Soil Sci Plant Nut. 1985;31:35-42.

30. Maljanen M, Yli-Pirilä P, Hytönen J, Joutsensaari J, Martikainen PJ. Acidic northern soils as sources of atmospheric nitrous acid (HONO). Soil Biol Biochem. 2013;67:94-7.

31. Ciais P, Sabine C, Bala G, Bopp L, Brovkin V, Canadell J, et al. Carbon and other biogeochemical cycles. In: Stocker TF, Qin D, Plattner G-K, Tignor M, Allen SK, Boschung J, et al. eds. Climate Change 2013 - The Physical Science Basis: Working Group I Contribution to the Fifth Assessment Report of the Intergovernmental Panel on Climate Change. Cambridge: Cambridge University Press; 2013. p. 465-570.

32. Williams EJ, Hutchinson GL, Fehsenfeld FCNOx. and $\mathrm{N}_{2} \mathrm{O}$ emissions from soil. Glob Biogeochem Cycles. 1992;6:351-88.

33. Davidson E, Matson P, Vitousek P, Riley R, Dunkin K, Garcia-Mendez G, et al. Processes regulating soil emissions of $\mathrm{NO}$ and $\mathrm{N}_{2} \mathrm{O}$ in a seasonally dry tropical forest. Ecology. 1993;74:130-9.

34. Caranto JD, Lancaster KM. Nitric oxide is an obligate bacterial nitrification intermediate produced by hydroxylamine oxidoreductase. Proc Natl Acad Sci USA. 2017;114:8217-22.

35. Lipschultz F, Zafiriou OC, Wofsy SC, McElroy MB, Valois FW, Watson SW. Production of $\mathrm{NO}$ and $\mathrm{N}_{2} \mathrm{O}$ by soil nitrifying bacteria. Nature. 1981;294:641-3.

36. Donaldson MA, Bish DL, Raff JD. Soil surface acidity plays a determining role in the atmospheric-terrestrial exchange of nitrous acid. Proc Natl Acad Sci USA. 2014;111:18472-7.

37. Kim M, Or D. Microscale pH variations during drying of soils and desert biocrusts affect $\mathrm{HONO}$ and $\mathrm{NH}_{3}$ emissions. Nat Commun. 2019;10:3944.

38. Ermel M, Behrendt T, Oswald R, Derstroff B, Wu D, Hohlmann S, et al. Hydroxylamine released by nitrifying microorganisms is a precursor for HONO emission from drying soils. Sci Rep. 2018;8:1877.

39. Scharko NK, Schütte UME, Berke $A E$, Banina $L$, Peel HR, Donaldson MA, et al. Combined flux chamber and genomics approach links nitrous acid emissions to ammonia oxidizing bacteria and archaea in urban and agricultural soil. Environ Sci Technol. 2015;49:13825-34.

40. Bhattarai HR, Wanek W, Siljanen HMP, Ronkainen JG, Liimatainen M, Hu Y, et al. Denitrification is the major nitrous acid production pathway in boreal agricultural soils. Commun Earth Environ. 2021;2:54.

41. Wu D, Horn MA, Behrendt T, Müller S, Li J, Cole JA, et al. Soil HONO emissions at high moisture content are driven by microbial nitrate reduction to nitrite: tackling the HONO puzzle. Isme J. 2019;13:1688-99.

42. Rundel PW, Cowling RM. Biodiversity of the Succulent Karoo. In: Levin SA, editor. Encyclopedia of Biodiversity. Second Edition. Waltham: Academic Press; 2013. p. 485-90. 
43. Haarmeyer DH, Schmiedel U, Dengler J, Bosing BM. How does grazing intensity affect different vegetation types in arid Succulent Karoo, South Africa? Implications for conservation management. Biol Conserv. 2010;143:588-96.

44. Weber B, Tamm A, Maier S, Rodríguez-Caballero E. Biological soil crusts of the Succulent Karoo: a review. Afr J Range Forage Sci. 2018;35:335-50.

45. Johansson O, Olofsson J, Giesler R, Palmqvist K. Lichen responses to nitrogen and phosphorus additions can be explained by the different symbiont responses. N. Phytol. 2011;191:795-805.

46. Eickhorst T, Tippkötter R. Improved detection of soil microorganisms using fluorescence in situ hybridization (FISH) and catalyzed reporter deposition (CARD-FISH). Soil Biol Biochem. 2008;40:1883-91.

47. Van Nostrand J, He Z, Zhou J. Use of functional gene arrays for elucidating in situ biodegradation. Front Microbiol. 2012;3:339.

48. Van Nostrand JD, Yin H, Wu L, Yuan T, Zhou J. Hybridization of environmental microbial community nucleic acids by GeoChip. Methods Mol Biol. 2016;1399:183-96.

49. Siggins A, Gunnigle E, Abram F. Exploring mixed microbial community functioning: recent advances in metaproteomics. FEMS Microbiol Ecol. 2012;80:265-80.

50. Meixner FX, Yang WX. Biogenic emissions of nitric oxide and nitrous oxide from arid and semi-arid land. In: D'Odorico P, Porporato A, editors. Dryland Ecohydrology. Dordrecht. Netherlands: Springer; 2006. p. 233-55.

51. Behrendt T, Braker G, Song G, Pommerenke B, Dörsch P. Nitric oxide emission response to soil moisture is linked to transcriptional activity of functional microbial groups. Soil Biol Biochem. 2017;115:337-45.

52. Burns LC, Stevens RJ, Laughlin RJ. Production of nitrite in soil by simultaneous nitrification and denitrification. Soil Biol Biochem. 1996;28:609-16.

53. Svehla P, Bartacek J, Pacek L, Hrncirova H, Radechovsky J, Hanc A, et al. Inhibition effect of free ammonia and free nitrous acid on nitrite-oxidising bacteria during sludge liquor treatment: influence of feeding strategy. Chem Pap. 2014;68:871-8.

54. Giguere AT, Taylor AE, Suwa Y, Myrold DD, Bottomley PJ. Uncoupling of ammonia oxidation from nitrite oxidation: Impact upon nitrous oxide production in non-cropped Oregon soils. Soil Biol Biochem. 2017;104:30-8.

55. Placella SA, Firestone MK. Transcriptional response of nitrifying communities to wetting of dry soil. Appl Environ Microbiol. 2013;79:3294-302.

56. Bollmann A, Bär-Gilissen M-J, Laanbroek HJ. Growth at low ammonium concentrations and starvation response as potential factors involved in niche differentiation among ammonia-oxidizing bacteria. Appl Environ Microbiol. 2002;68:4751-7

57. Sayavedra-Soto LA, Hommes NG, Russell SA, Arp DJ. Induction of ammonia monooxygenase and hydroxylamine oxidoreductase mRNAs by ammonium in Nitrosomonas europaea. Mol Microbiol. 1996;20:541-8.

58. Bollmann A, Schmidt I, Saunders AM, Nicolaisen MH. Influence of starvation on potential ammonia-oxidizing activity and amoA mRNA levels of Nitrosospira briensis. Appl Environ Micro. 2005;71:1276-82.

59. van Rijn J, Tal Y, Barak Y. Influence of volatile fatty acids on nitrite accumulation by a Pseudomonas stutzeri strain isolated from a denitrifying fluidized bed reactor. Appl Environ Microbiol. 1996;62:2615-20.

60. Wang L, Tian J, Li Y. Nitrite accumulation and nitrous oxide emission during denitrification processes with quinoline or indole as the sole carbon source. J Chem Technol Biotechnol. 2015;90:1317-28.

61. Pepe-Ranney C, Koechli C, Potrafka R, Andam C, Eggleston E, Garcia-Pichel F, et al. Non-cyanobacterial diazotrophs mediate dinitrogen fixation in biological soil crusts during early crust formation. Isme J. 2016;10:287-98.

62. Couradeau E, Giraldo-Silva A, De Martini F, Garcia-Pichel F. Spatial segregation of the biological soil crust microbiome around its foundational cyanobacterium, Microcoleus vaginatus, and the formation of a nitrogen-fixing cyanosphere. Microbiome. 2019;7:55

63. Fernández-Martinez $M A$, Pointing $S B$, Pérez-Ortega $S$, Arróniz-Crespo $M$ Green TGA, Rozzi R, et al. Functional ecology of soil microbial communities along a glacier forefield in Tierra del Fuego (Chile). Int. Microbiol. 2016;19:1618-1095.

64. Zhao L, Liu Y, Wang Z, Yuan S, Qi J, Zhang W, et al. Bacteria and fungi differentially contribute to carbon and nitrogen cycles during biological soil crust succession in arid ecosystems. Plant Soil. 2020;447:379-92.

65. Brankatschk R, Fischer $T$, Veste $M$, Zeyer J. Succession of $N$ cycling processes in biological soil crusts on a Central European inland dune. Fems Microbiol Ecol. 2013;83:149-60.

66. Isobe $\mathrm{K}$, Ohte $\mathrm{N}$. Ecological perspectives on microbes involved in N-cycling. Microbes Environ. 2014;29:4-16.

67. Canfield DE, Glazer AN, Falkowski PG. The evolution and future of Earth's nitrogen cycle. Science. 2010;330:192-6.

68. Wrage $N$, Velthof $G L$, van Beusichem $M L$, Oenema O. Role of nitrifier denitrification in the production of nitrous oxide. Soil Biol Biochem. 2001;33:1723-32.
69. Giagnoni L, Magherini F, Landi L, Taghavi S, Modesti A, Bini L, et al. Extraction of microbial proteome from soil: potential and limitations assessed through a model study. Eur J Soil Sci. 2011;62:74-81.

70. Bastida F, Hernández T, García C. Metaproteomics of soils from semiarid environment: functional and phylogenetic information obtained with different protein extraction methods. J Proteom. 2014;101:31-42.

71. Bastida F, Moreno JL, Nicolás C, Hernández T, García C. Soil metaproteomics: a review of an emerging environmental science. Significance, methodology and perspectives. Eur J Soil Sci. 2009;60:845-59.

72. Becher D, Bernhardt J, Fuchs S, Riedel K. Metaproteomics to unravel major microbial players in leaf litter and soil environments: challenges and perspectives. Proteomics. 2013;13:2895-909.

73. Katoh H, Asthana RK, Ohmori M. Gene expression in the cyanobacterium Anabaena sp. PCC7120 under desiccation. Micro Ecol. 2004;47:164-74.

74. Lebre $\mathrm{PH}$, De Maayer $\mathrm{P}$, Cowan DA. Xerotolerant bacteria: surviving through a dry spell. Nat Rev Microbiol. 2017;15:285-96.

75. Katoh $\mathrm{H}$. Desiccation-inducible genes are related to $\mathrm{N}_{2}$-fixing system under desiccation in a terrestrial cyanobacterium. Biochim Biophys Acta. 2012;1817: 1263-9.

76. Sawers RG. Dormancy: Illuminating how a microbial sleeping beauty awakens. Curr Biol. 2016;26:R1139-R41.

77. Blazewicz SJ, Schwartz E, Firestone MK. Growth and death of bacteria and fungi underlie rainfall-induced carbon dioxide pulses from seasonally dried soil. Ecology. 2014;95:1162-72.

78. Placella SA, Brodie EL, Firestone MK. Rainfall-induced carbon dioxide pulses result from sequential resuscitation of phylogenetically clustered microbial groups. Proc Natl Acad Sci USA. 2012;109:10931-6.

79. Barnard RL, Osborne CA, Firestone MK. Responses of soil bacterial and fungal communities to extreme desiccation and rewetting. ISME J. 2013;7:2229-41.

80. Swenson TL, Karaoz U, Swenson JM, Bowen BP, Northen TR. Linking soil biology and chemistry in biological soil crust using isolate exometabolomics. Nat Commun. 2018;9:19.

81. Zaady $E$, Groffman PM, Standing D, Shachak M. High $\mathrm{N}_{2} \mathrm{O}$ emissions in dry ecosystems. Eur J Soil Biol. 2013;59:1-7.

82. Wilske B, Burgheimer J, Karnieli A, Zaady E, Andreae MO, Yakir D, et al. The $\mathrm{CO}_{2}$ exchange of biological soil crusts in a semiarid grass-shrubland at the northern transition zone of the Negev desert, Israel. Biogeosciences. 2008;5:1411-23.

83. Abed RMM, Lam $P$, de Beer $D$, Stief $P$. High rates of denitrification and nitrous oxide emission in arid biological soil crusts from the Sultanate of Oman. Isme J. 2013;7:1862-75.

84. Sedlacek CJ, Giguere AT, Dobie MD, Mellbye BL, Ferrell RV, Woebken D, et al. Transcriptomic response of Nitrosomonas europaea transitioned from ammoniato oxygen-limited steady-state growth. mSystems. 2020;5:1.

85. O'Donnell M, Langston L, Stillman B. Principles and concepts of DNA replication in bacteria. Archaea, Eukarya Csh Perspect Biol. 2013;5:7.

86. Wuchter C, Abbas B, Coolen MJL, Herfort L, van Bleijswijk J, Timmers $P$, et al. Archaeal nitrification in the ocean. Proc Natl Acad Sci USA. 2006;103:12317-22.

87. Leininger S, Urich T, Schloter M, Schwark L, Qi J, Nicol GW, et al. Archaea predominate among ammonia-oxidizing prokaryotes in soils. Nature. 2006;442:806-9.

88. Marusenko Y, Garcia-Pichel F, Hall SJ. Ammonia-oxidizing archaea respond positively to inorganic nitrogen addition in desert soils. FEMS Microbiol Ecol. 2015;91:1-11.

89. Sullivan BW, Selmants PC, Hart SC. New evidence that high potential nitrification rates occur in soils during dry seasons: are microbial communities metabolically active during dry seasons? Soil Biol Biochem. 2012;53:28-31.

90. Delgado-Baquerizo M, Maestre FT, Eldridge DJ, Singh BK. Microsite differentiation drives the abundance of soil ammonia oxidizing bacteria along aridity gradients. Front Microbiol. 2016;7:505.

91. Strauss SL, Day TA, Garcia-Pichel F. Nitrogen cycling in desert biological soil crusts across biogeographic regions in the Southwestern United States. Biogeochemistry. 2012;108:171-82.

92. Körner H, Zumft WG. Expression of denitrification enzymes in response to the dissolved oxygen level and respiratory substrate in continuous culture of Pseudomonas stutzeri. Appl Environ Microbiol. 1989;55:1670-6.

93. GarciaPichel F, Belnap J. Microenvironments and microscale productivity of cyanobacterial desert crusts. J Phycol. 1996;32:774-82.

94. Abed RMM, Polerecky L, Al-Habsi A, Oetjen J, Strous M, de Beer D. Rapid recovery of cyanobacterial pigments in desiccated biological soil crusts following addition of water. PLOS ONE. 2014;9:e112372.

95. Wei X, Yan T, Hommes NG, Liu X, Wu L, McAlvin C, et al. Transcript profiles of Nitrosomonas europaea during growth and upon deprivation of ammonia and carbonate. FEMS Microbiol Lett. 2006;257:76-83. 
96. Betts JC, Lukey PT, Robb LC, McAdam RA, Duncan K. Evaluation of a nutrient starvation model of Mycobacterium tuberculosis persistence by gene and protein expression profiling. Mol Microbiol. 2002;43:717-31.

97. Chenu C, Stotzky G. Interactions between microorganisms and soil particles: an overview. In: Huang PM, Bollag J-M, Senesi N, editors. Interactions between soil particles and microorganisms: Impact on the terrestrial ecosystem. Chichester, UK: John Wiley \& Sons Ltd; 2001. p. 3-40.

98. Ranjard L, Richaume A. Quantitative and qualitative microscale distribution of bacteria in soil. Microbiol Res. 2001;152:707-16.

99. Nunan N, Wu K, Young IM, Crawford JW, Ritz K. Spatial distribution of bacterial communities and their relationships with the micro-architecture of soil. FEMS Microbiol Ecol. 2003;44:203-15.

100. Grundmann GL, Debouzie D. Geostatistical analysis of the distribution of $\mathrm{NH}_{4}{ }^{+}$ and $\mathrm{NO}_{2}{ }^{-}$-oxidizing bacteria and serotypes at the millimeter scale along a soil transect. FEMS Microbiol Ecol. 2000;34:57-62.

101. Or D, Smets BF, Wraith JM, Dechesne A, Friedman SP. Physical constraints affecting bacterial habitats and activity in unsaturated porous media - a review. Adv Water Resour. 2007;30:1505-27.

102. Tecon R, Or D. Biophysical processes supporting the diversity of microbial life in soil. FEMS Microbiol Rev. 2017;41:599-623.

103. Young IM, Ritz K. Tillage, habitat space and function of soil microbes. Soil Tillage Res. 2000;53:201-13.

\section{ACKNOWLEDGEMENTS}

Research described within this paper has been funded and supported by the Max Planck Society (Nobel Laureate Fellowship to BW) and was supported by the Max Planck Graduate Center with the Johannes Gutenberg University, Mainz (MPGC fellowship to AMK). We would like to thank C. Pöhlker for his great support and many fruitful discussions and G. Borngässer and S. Klassen for conducting the $\mathrm{NO}_{3}{ }^{-}$and $\mathrm{NO}_{2}{ }^{-}$analyses. Special thanks to J. Fröhlich-Nowoisky and K. Lucas for providing laboratory facilities. We would like to thank $E$. Thines for valuable suggestions and his overall support. Sampling was conducted according to research permit FLORA 0018/ 2017 and the appending export permit provided by the Department of Environment and Nature Conservation of Northern Cape, South Africa, located in Kimberley.

\section{AUTHOR CONTRIBUTIONS}

BW, SM, and AMK conceived the study. The measurements and data analyses were performed by SM, AMK, and JW with assistance from MP and TE (FISH), FL (metaproteomics), HS and YC (dynamic chamber measurements), SF (soil analyses), and ATC (statistical analyses). BW, SM, AMK, and JW wrote the paper with major input from UP, HS, YC, ET, and RMMA and further input from all the other authors.

\section{FUNDING}

Open Access funding enabled and organized by Projekt DEAL.

\section{COMPETING INTERESTS}

The authors declare no competing interests.

\section{ADDITIONAL INFORMATION}

Supplementary information The online version contains supplementary material available at https://doi.org/10.1038/s41396-021-01127-1.

Correspondence and requests for materials should be addressed to S. Maier or B. Weber.

Reprints and permission information is available at http://www.nature.com/ reprints

Publisher's note Springer Nature remains neutral with regard to jurisdictional claims in published maps and institutional affiliations.

(i) Open Access This article is licensed under a Creative Commons Attribution 4.0 International License, which permits use, sharing, adaptation, distribution and reproduction in any medium or format, as long as you give appropriate credit to the original author(s) and the source, provide a link to the Creative Commons license, and indicate if changes were made. The images or other third party material in this article are included in the article's Creative Commons license, unless indicated otherwise in a credit line to the material. If material is not included in the article's Creative Commons license and your intended use is not permitted by statutory regulation or exceeds the permitted use, you will need to obtain permission directly from the copyright holder. To view a copy of this license, visit http://creativecommons. org/licenses/by/4.0/.

(C) The Author(s) 2021 